DOI: $10.5800 / G T-2021-12-4-0565$

\title{
COMPARATIVE ANALYSIS OF NEOGEODYNAMICS OF THE BALTIC SYNECLISE AND THE NORTHERN SLOPE OF THE VORONEZH ANTECLISE
}

\author{
A.0. Agibalov ${ }^{1}{ }^{1}$, V.A. Zaitsev ${ }^{2}{ }^{2}$, A.A. Sentsov ${ }^{1 凶}{ }^{1 凶}$ \\ ${ }^{1}$ Schmidt Institute of Physics of the Earth, Russian Academy of Sciences, 10-1 Bolshaya Gruzinskaya St, Moscow \\ 123242, Russia \\ ${ }^{2}$ Lomonosov Moscow State University, 1 Leninskie Gory, Moscow 119991, Russia
}

\begin{abstract}
The paper presents the results of comparative neogeodynamic analysis of the Baltic syneclise and northern Voronezh anteclise based on structural-geomorphological interpretation, digital elevation model (DEM) processing procedure using LESSA program [Zlatopolsky, 2011], seismic analysis, and computer geodynamic modeling.

Both regions are seismically active areas of the East European Platform. The automated DEM analysis showed that they are dominated by NW-striking lineaments oriented across the strike of the neoextension axis. Computational neogeodynamic models imply that the areas under consideration develop in shear environment, with the compression axis oriented northwest. Another important result of modeling is numerical correlation between earthquake energy, interpolated over the Baltic syneclise, and the probability of occurrence of ruptures: the Pearson correlation coefficient is 0.58 for the sedimentary cover and 0.42 for the basement. For the northern Voronezh anteclise, a correlation was found between the epicentral density of earthquakes and "Fracture regions" parameter, with reference to which there were distinguished the areas with the probable occurrence of new short-extension ruptures (the Pearson correlation coefficient is 0.41 ). This parameter is informative for contouring seismically active parts since the areas with probable occurrence of new ruptures, occupying $39 \%$ of the northern Voronezh anteclise, account for $71 \%$ of earthquake epicenters. Structuralgeomorphological interpretation yielded a high degree of correlation between relief and active faults identified as "weak" zones to which the earthquake epicenters are largely confined. Therefore, both regions considered are characterized by high sedimentary-cover seismic activity, develop in shear stress field, with the stress axis oriented northwest, and have similar orientations of linear elements of relief and "weak" zones.

The analysis of the earthquake recurrence curves shows considerable differences between seismic regimes of the northern Voronezh anteclise and the Baltic syneclise, and those between the sedimentary-cover and basement seismicity of the latter. These differences may be due the fact that the stressed state of the Voronezh anteclise is affected by active structures of the Urals and Caucasus, and that the upwarping Fennoscandian shield is largely responsible for neodeformations of the Baltic syneclise.

Practical significance of the study is concerned with the identification of earthquake source zones.
\end{abstract}

KEYWORDS: seismotectonics; neotectonics; computer modeling; structural and geomorphological analysis; GIS technologies

FUNDING: The study was funded from the state budget of the IPE RAS.

\section{RESEARCH ARTICLE}

Correspondence: Alexey A. Sentsov, alekssencov@yandex.ru
Received: September 16, 2020

Revised: June 2, 2021

Accepted: June 14, 2021

FOR CITATION: Agibalov A.O., Zaitsev V.A., Sentsov A.A., 2021. Comparative analysis of neogeodynamics of the Baltic syneclise and the northern slope of the Voronezh anteclise. Geodynamics \& Tectonophysics 12 (4), 951-968. doi:10.5800/GT-2021-12-4-0565 


\title{
СРАВНИТЕЛЬНЫЙ АНАЛИЗ НОВЕЙШЕЙ ГЕОДИНАМИКИ БАЛТИЙСКОЙ СИНЕКЛИЗЫ И СЕВЕРНОГО СКЛОНА ВОРОНЕЖСКОЙ АНТЕКЛИЗЫ
}

\author{
А.О. Агибалов ${ }^{1}$, В.А. Зайцев ${ }^{2}$, А.А. Сенцов ${ }^{1}$
}

${ }^{1}$ Институт физики Земли им. О.Ю. Шмидта РАН, 123242, Москва, ул. Большая Грузинская, 10, стр. 1, Россия

${ }^{2}$ Московский государственный университет им. М.В. Ломоносова, 119991, Москва, Ленинские горы, 1 , Россия

\begin{abstract}
АННОТАЦИЯ. В статье изложены результаты сравнительного анализа новейшей геодинамики Балтийской синеклизы и северной части Воронежской антеклизы, для проведения которого использованы структурно-геоморфологическое дешифрирование, обработка цифровой модели рельефа (ЦМР) в программе LESSA [Zlatopolsky, 2011], анализ сейсмичности и компьютерное геодинамическое моделирование.

Оба региона относятся к сейсмоактивным областям Восточно-Европейской платформы. Автоматизированный анализ ЦМР показал, что в их пределах преобладают линеаменты северо-западного направления, ориентированные вкрест простирания оси растяжения на новейшем этапе. Компьютерные модели новейшей геодинамики предполагают, что рассматриваемые области развиваются в сдвиговой обстановке при ориентировке оси сжатия в северо-западных румбах. Другим значимым результатом моделирования является численная корреляция между энергией землетрясений, интерполированной на всю территорию Балтийской синеклизы, и вероятностью формирования трещин отрыва: коэффициент корреляции Пирсона составляет 0.58 для осадочного чехла и 0.42 для фундамента. Для северной части Воронежской антеклизы установлена корреляция между плотностью эпицентров землетрясений и параметром «Fracture regions», по которому выделены области возможного формирования новых разрывов малой протяженности (коэффициент корреляции Пирсона 0.41). Этот параметр информативен для оконтуривания сейсмоактивных участков, поскольку в области возможного формирования новых разрывов, занимающих 39 \% площади северной части Воронежской антеклизы, попадает 71 \% эпицентров землетрясений. По данным структурно-геоморфологического дешифрирования установлена высокая степень взаимосвязи между рельефом и активными разломами, выделяемыми как «слабые» зоны. К последним приурочено большинство эпицентров землетрясений. Таким образом, оба изучаемых региона отличаются высокой для областей развития плитного чехла сейсмической активностью, развиваются в сдвиговом поле напряжений при ориентировке оси сжатия в северо-западном направлении и характеризуются сходными ориентировками линейных элементов рельефа и «слабых» зон.
\end{abstract}

Анализ графиков повторяемости землетрясений показывает существенные различия сейсмических режимов северной части Воронежской антеклизы и Балтийской синеклизы, а также разный характер сейсмичности в чехле и фундаменте последней. Возможно, эти отличия связаны с тем, что на напряженное состояние Воронежской антеклизы влияют активные структуры Урала и Кавказа, а испытывающий воздымание Фенноскандинавский щит во многом обусловливает новейшие деформации Балтийской синеклизы.

Прикладное значение исследования заключается в выделении нами зон возможных очагов землетрясений.

КЛЮЧЕВЫЕ СЛОВА: сейсмотектоника; неотектоника; компьютерное моделирование; структурно-геоморфологический анализ; ГИС-технологии

ФИНАНСИРОВАНИЕ: Исследование выполнено в рамках госбюджетной темы ИФЗ РАН.

\section{1. ВВЕДЕНИЕ}

Изучение новейшей геодинамики Восточно-Европейской платформы (ВЕП) представляется актуальной проблемой, имеющей не только фундаментальное, но и прикладное значение, обусловленное необходимостью прогноза землетрясений. Кроме уточнения сейсмического прогноза по основным трем параметрам (времени, месту и энергии), важно установить региональное напряженное состояние, оказывающее влияние на характер сейсмичности.

В статье рассмотрены Балтийская синеклиза и северный склон Воронежской антеклизы. Проведение сравнительного анализа этих территорий интересно тем, что они отличаются друг от друга геологическим строением, характером сейсмичности и т.д. и в то же время существуют общие для обоих регионов геолого-геоморфологические особенности. Во-первых, Балтийская синеклиза и Воронежская антеклиза относятся к сейсмоактивным участкам ВЕП: в их пределах происходили относительно сильные землетрясения, максимальные магнитуды которых составляют 4.8 для Балтийской синеклизы (Калининградское землетрясение 2004 г.) и 3.8 - для северной части Воронежской антеклизы (Никольское землетрясение 2000 г.). Во-вторых, оба рассматриваемых района расположены вблизи щитов - Фенноскандинавского (Балтийского) и Украинского, которые могут оказывать воздействие на новейшие деформации и сейсмичность сопредельных территорий как источники неотектонических напряжений. В-третьих, Балтийская синеклиза 
и Воронежская антеклиза относятся к внутриплатформенным геодинамическим системам, в пределах которых локализованы собственные источники новейших напряжений. В то же время они испытывают воздействие более крупных внеплатформенных геодинамических систем - Скандинавской, Альпийской и Уральской [Makarova et al., 2016]. Определенное влияние на характер новейшей геодинамической активности Воронежской антеклизы может также оказывать впадина Каспийского моря [Makarov, 1996; Yudakhin et al., 2003]. Для территории Балтийской синеклизы подобным внешним источником тектонических напряжений служит спрединговая зона Северной Атлантики [Makarova et al., 2016]. Кроме того, проведенные нами исследования позволили сделать выводы о сходстве ориентировок внешних главных нормальных осей новейших напряжений и линейных элементов рельефа северной части Воронежской антеклизы и Балтийской синеклизы.

Несмотря на то, что в настоящее время накоплен большой объем информации о новейшей геодинамике и сейсмотектонике Балтийской синеклизы [Levkov, Karabanov, 1994; Sim et al., 1995; Makeev, 2015; Nikonov, 1977; Sharov et al., 2007; Garetsky, Nesmeyanov, 2009; Rogozhin et al., 2014a, 2014b] и Воронежской антеклизы [Tregub, 2001, 2005; Tregub et al., 2015; Raskatov, 1969], определенные исследовательские задачи остаются недостаточно проработанными. К ним относятся проблемы анализа новейшего напряженного состояния, создания компьютерных моделей, объясняющих сейсмотектоническую активность, выделения зон возможных очагов землетрясений (В03) с учетом современных данных о сейсмичности.

\section{2. МАТЕРИАЛЫ И МЕТОДЫ ИССЛЕДОВАНИЯ}

Для выполнения сравнительного анализа новейшей геодинамики Балтийской синеклизы и северного склона Воронежской антеклизы проводились структурно-геоморфологическое дешифрирование, автоматизированная обработка (ЦМР) в программе LESSA [Zlatopolsky, 2011] , анализ сейсмичности и компьютерное геодинамическое моделирование.

Методика структурно-геоморфологического дешифрирования предполагает выявление «слабых» зон по комплексу геоморфологических признаков: рисунку эрозионной сети, очертаниям береговых линий озер, расположению вертикальных стенок и уступов, перегибам склонов и т.п. [Kostenko, 1999; Panina, 2019]. «Слабые» зоны представляют собой линейные элементы эрозионной сети, разделяющие разновысотные блоки, и традиционно интерпретируются как зоны трещиноватости, повышенной проницаемости, скрытые разрывные нарушения [Kostenko, 1999]. Нами проводилось структурно-геоморфологическое дешифрирование ЦМР, космических изображений и топографических карт в масштабе 1:500000, позволившее выявить «слабые» зоны и построить роза-диаграммы, иллюстрирующие их ориентировку. Для сопоставления роза-диаграмм проведен расчет средних круговых знчений $\left(m_{g}\right)$ и выборочных мод $\left(M_{g}\right)$ по формулам:

$$
\begin{gathered}
m_{g}=\left\{\operatorname{arctg} \frac{S}{C}+\frac{\pi}{2}\{2-(\operatorname{sign} S)[1+(\operatorname{sign} C)]\}(\bmod 2 \pi)\right\} \\
M_{g}=l+\frac{f_{0}-f_{-1}}{2 f_{0}-f_{-1}-f_{+1}} \cdot h
\end{gathered}
$$

где $C=\frac{1}{n} \sum_{i=1}^{k} a_{i} \cos b_{i} ; S=\frac{1}{n} \sum_{i=1}^{k} a_{i} \sin b_{i} ; b_{i}-$ средняя точка $i$-го интервала группировки, $a_{i}$ - частота, соответствующая $i$-му интервалу, $l$ - нижний предел модального класс-интервала (т.е. класс-интервала с наибольшей частотой $\left.f_{0}\right), f_{-1}$ и $f_{+1}$ - частота соответственно предшествующего и следующего за модальным классинтервала, $h$ - ширина модального класс-интервала. Более подробно методика расчета указанных параметров рассмотрена в монографии [Mardia, 1978]. Наиболее протяженные и хорошо выраженные в рельефе «слабые» зоны северного склона Воронежской антеклизы, приуроченные к разломам фундамента, интерпретируются нами как активные разломы, информация о конфигурации которых использована для разработки компьютерной модели новейшей геодинамики. Кроме того, проведено сопоставление пространственного рисунка «слабых» зон и расположения эпицентров землетрясений в пределах обеих рассматриваемых областей.

Автоматизированный анализ ЦМР в программе LESSA [Zlatopolsky, 2011] дополняет результаты структурногеоморфологического дешифрирования. Использование этой программы позволило составить роза-диаграммы, иллюстрирующие ориентировку линеаментов«штрихов», соответствующих спрямленным участкам эрозионной сети. Как показано в работе [Panina et al., 2021], их расположение в ряде случаев связано с ориентировкой главных нормальных осей новейших напряжений.

Для того чтобы проанализировать характер распределения эпицентров сейсмических событий по площади, построить схемы их плотности, энергии землетрясений, графики повторяемости, составлен сводный сейсмологический каталог, включающий данные работ [New Catalog..., 1977; USGS Earthquake, 2019; Seismic Catalogues..., 2020; Garetsky, Nesmeyanov, 2009]. Приведенный в монографии [Garetsky, Nesmeyanov, 2009] каталог является достаточно подробным, при его составлении учитывались материалы [Lutikov et al., 2005; Nikonov, 2008; Guterch, Levandowska-Marciniak, 2002; Uski, Pelkomen, 2004]. Также нами рассмотрены результаты сейсмологических наблюдений, полученные лабораторией сейсмического мониторинга Воронежского кристаллического массива с 1998 по 2012 г. Мониторинг проводился с использованием местной сейсмической сети, состоявшей из семи цифровых и одной аналоговой станции, которые были оснащены сейсмометрами типа СМЗ-КВ и СМЗ-ОС, регистрирующими события в широком диапазоне частот - от 0.02 до 20,00 Гц 
[Nadezhka et al., 2010; Efremenko, 2011]. Отметим, что для каждого землетрясения, произошедшего на территории Воронежского массива, указан его энергетический класс. Для того чтобы объединить результаты этого сейсмического мониторинга с данными [USGS Earthquake..., 2019; Seismic Catalogues..., 2020; Garetsky, Nesmeyanov, 2009], нами проведен пересчет энергетического класса в энергию, а затем в магнитуду по следующим формулам: $K_{s}=\lg E ; \lg E=4.8+1.5 M_{s^{\prime}} \lg E=-1.2+2.4 m_{b}$ (предложена Рихтером) и $m_{b}=2.3+0.63 M_{s}$ (зависимость Гутенберга - Рихтера) [Gutenberg, Richter, 1956; Storcheus, 2008, 2011; Zakharov, Smirnov, 2016], где $K_{s}$ - энергетический класс землетрясения, $E$ - энергия землетрясения (в Дж), $M_{s}$ - магнитуда по поверхностным волнам, $m_{b}$ - магнитуда объемных волн. Из этих формул следует, что

$$
M_{s}=\frac{\frac{K_{s}+1.2}{2.4}-2.3}{0.63} .
$$

К сожалению, в использованных каталогах не приводятся данные о погрешности инструментальных наблюдений по оценке глубин очагов. Также отметим, что каталоги отличаются степенью представительности: на территории Воронежской антеклизы размещена местная сейсмическая сеть, позволяющая фиксировать достаточно слабые события, в то время как на Балтийской синеклизе такой сети нет, поэтому каталог не содержит информации о землетрясениях с $M_{s}<1.8$. Из составленного нами сводного сейсмологического каталога Балтийской синеклизы и северной части Воронежской антеклизы исключена информация о техногенной сейсмичности. Построение графиков повторяемости, а также расчет сейсмической энергии проводились на основе данных о магнитудах поверхностных волн $\left(M_{s}\right)$. В табл. 1 и 2 приведена информация о распределении землетрясений по магнитудам и годам, на основании которых составлены графики повторяемости землетрясений.

При проведении компьютерного моделирования новейшей геодинамики использовались ЦМР, данные о глубине поверхности фундамента Балтийской синеклизы [Zakashansky, 1963; Jubitz, 1983], батиметрическая карта Балтийского моря [Rudenko, Ryazheva, 2004], физико-механические параметры среды (коэффициенты Пуассона и внутреннего трения), информация о конфигурации достоверных и предполагаемых активных разломов. Моделирование выполнено в программе Reservoir Modeling System (RMS) 2013 компании «ROXAR». Этот программный продукт является коммерческим и традиционно используется в нефтегазовой геологии для 3D-моделирования месторождений, планирования их разработки и подсчета запасов. Методика работ заключалась в том, что по высотным отметкам рельефа (в том числе подводного) и поверхности фундамента были построены поверхности в формате «Grid», на которые нанесена сетка активных разломов. С помощью модуля «Fracture modeling» заданы осредненные значения коэффициентов Пуассона (0.25) и внутреннего трения (0.6), а также ориентировки внешних главных нормальных осей напряжений. В работе [Analysis..., 2012] отмечено, что моделирование с использованием указанных значений геомеханических констант является допустимым, поскольку они принципиально не влияют на результаты расчетов. Нами заданы различные ориентировки внешних нагрузок: азимуты простирания осей сжатия и растяжения варьируются от 0 до $165^{\circ}$ с шагом в $15^{\circ}$. В качестве наиболее достоверных выбраны те модели, для которых достигнуто наилучшее соответствие между реальными характеристиками геологической среды (энергия землетрясений, плотность эпицентров сейсмических событий) и полученными в результате моделирования параметрами. К последним относятся

Табл. 1. Распределение количества сейсмических событий Балтийской синеклизы по магнитудам поверхностных волн и годам

Table 1. Distribution of the number of seismic events of the Baltic syneclise by surface wave magnitude and years

\begin{tabular}{|c|c|c|c|c|c|c|c|c|c|}
\hline \multirow{3}{*}{ Годы } & \multicolumn{9}{|c|}{ Магнитуда поверхностных волн } \\
\hline & 1 & 1.5 & 2 & 2.5 & 3 & 3.5 & 4 & 4.5 & 5 \\
\hline & {$[1.0-1.5]$} & {$[1.5-2.0]$} & {$[2.0-2.5]$} & {$[2.5-3.0]$} & {$[3.0-3.5]$} & {$[3.5-4.0]$} & {$[4.0-4.5]$} & {$[4.5-5.0]$} & {$[5.0-5.5]$} \\
\hline $1896-1923$ & 0 & 0 & 0 & 0 & 1 & 1 & 0 & 0 & 0 \\
\hline 1924-1956 & 0 & 0 & 1 & 2 & 0 & 0 & 0 & 0 & 0 \\
\hline 1957-1966 & 0 & 0 & 0 & 0 & 0 & 0 & 0 & 0 & 0 \\
\hline $1967-1976$ & 0 & 0 & 0 & 1 & 0 & 0 & 0 & 0 & 0 \\
\hline 1977-1986 & 0 & 0 & 0 & 0 & 2 & 0 & 0 & 0 & 0 \\
\hline 1987-1991 & 1 & 0 & 3 & 2 & 2 & 3 & 0 & 0 & 0 \\
\hline 1992-1996 & 0 & 0 & 0 & 8 & 1 & 2 & 5 & 3 & 0 \\
\hline 1997-2001 & 0 & 0 & 0 & 0 & 0 & 0 & 0 & 0 & 0 \\
\hline $2002-2006$ & 0 & 0 & 11 & 16 & 8 & 0 & 5 & 2 & 1 \\
\hline $2007-2011$ & 2 & 0 & 0 & 0 & 0 & 0 & 0 & 0 & 0 \\
\hline
\end{tabular}


Табл. 2. Распределение количества сейсмических событий северного склона Воронежской антеклизы по магнитудам поверхностных волн и годам

Table 2. Distribution of the number of seismic events on the northern slope of the Voronezh anteclise by surface wave magnitudes and years

\begin{tabular}{lccccc}
\hline & \multicolumn{5}{c}{ Магнитуда поверхностных волн } \\
\cline { 2 - 6 } Годы & 1 & 1.5 & 2 & 2.5 & 3 \\
\cline { 2 - 6 } & {$[1.0-1.5)$} & {$[1.5-2.0)$} & {$[2.0-2.5)$} & {$[2.5-3.0)$} & {$[3.0-3.5)$} \\
\hline $1996-2000$ & 16 & 12 & 14 & 3 & 1 \\
$2001-2005$ & 70 & 46 & 26 & 4 & 4 \\
$2006-2010$ & 1 & 11 & 3 & 2 & 0 \\
$2011-2015$ & 4 & 3 & 0 & 0 & 0 \\
$2016-2020$ & 1 & 3 & 1 & 0 & 0 \\
\hline
\end{tabular}

«вероятность формирования трещин отрыва» и «области возможного формирования новых разрывов малой протяженности (Fracture regions)». Возможность сопоставления этих параметров с сейсмичностью обоснована в работе [King, Cocco, 2001]. Предполагается, что модель состоит из упругого однородного материала, основные физико-механические свойства которого заданы как начальные условия. Кроме того, принимается ряд допущений о геометрии активных разломов (они не должны пересекаться), величинах напряжений, считающихся достаточными для возникновения новых разрывов малой протяженности. Под воздействием внешней нагрузки в связи с влиянием активных разломов, рассматриваемых как вертикальные неоднородности, происходит перераспределение напряжений, в результате чего на некоторых площадках достигается сочетание нормального и касательного напряжения, приводящее, согласно теории Мора, к нарушению прочности и возникновению новых разломов. Модели ограничивались глубиной в 25 км из-за того, что на ней находится граница между пластическими зонами сиалической и мафической коры [Ivanov S.N., Ivanov K.S., 2018]. Более подробно методика моделирования, используемые допущения и математические алгоритмы рассмотрены в работе [Analysis..., 2012] (раздел «RMS Fracture») и в статье [Agibalov et al., 2017].

Выделение зоны В03 проведено по максимумам плотности эпицентров землетрясений с учетом расположения областей возможного формирования новых разрывов малой протяженности: все зоны ВОЗ расположены в пределах этих областей и отличаются высокими значения плотности эпицентров сейсмических событий.

\section{3. РЕЗУЛЬТАТЫ И ИХ ОБСУЖДЕНИЕ. АНАЛИЗ НОВЕЙШЕЙ ГЕОДИНАМИКИ БАЛТИЙСКОЙ СИНЕКЛИЗЫ}

На новейшем этапе центральная часть Балтийской синеклизы представляет собой область опускания, граничащую на северо-западе и юго-востоке с ЭстонскоКурземской и Литовско-Восточно-Латвийской областями поднятий. Амплитуды неотектонических опусканий в центральной части синеклизы достигают 200 м [Garetsky et al., 1999]. На рассматриваемой территории происходили активные гляциоизостатические движения, амплитуды которых после завершения последнего (поздневалдайского) оледенения соизмеримы с амплитудами вертикальных перемещений за весь неотектонический этап (36-37 млн лет) [Shik et al., 2004; Garetsky, Nesmeyanov, 2009]. Эти процессы обусловили активизацию погребенных докембрийских разрывных нарушений, сопровождающуюся сейсмичностью. Более подробно основные черты новейшей тектоники Балтийской синеклизы описаны в монографии [Garetsky, Nesmeyanov, 2009].

В результате структурно-геоморфологического дешифрирования нами была построена карта блоковой делимости Балтийской синеклизы (рис. 1).

Установлено, что основными направлениями простирания «слабых» зон являются субмеридиональное, диагональные (северо-западное и северо-восточное) и субширотное (по мере уменьшения значимости), величины $m_{g}$ и $M_{g}$ равны 96.9 и $186.0^{\circ}$ соответственно (рис. 2).

В некоторых случаях эти зоны наследуют глубинные структуры. Например, одна из «слабых» зон совпадает с разломом, протягивающимся в субширотном направлении от Калининградского залива в глубь континента примерно до $23^{\circ}$ восточной долготы [Rogozhin et al., 2010; Rogozhin, 2012]. По данным [Sharov et al., 2007], точно такую же ориентировку имеет значительная часть новейших активных разрывных нарушений в смежных регионах. Отметим, что все эпицентры сейсмических событий приурочены к «слабым» зонам.

Анализ сейсмичности показал, что за инструментальный период наблюдений на территории Балтийской синеклизы произошло 85 землетрясений, гипоцентры 24 из них локализованы в пределах кристаллического фундамента. Отдельное рассмотрение сейсмичности в осадочном чехле и фундаменте связано с различиями физических свойств слагающих их пород и разным характером сейсмотектонических процессов: 1) большинство эпицентров землетрясений расположено на малых 


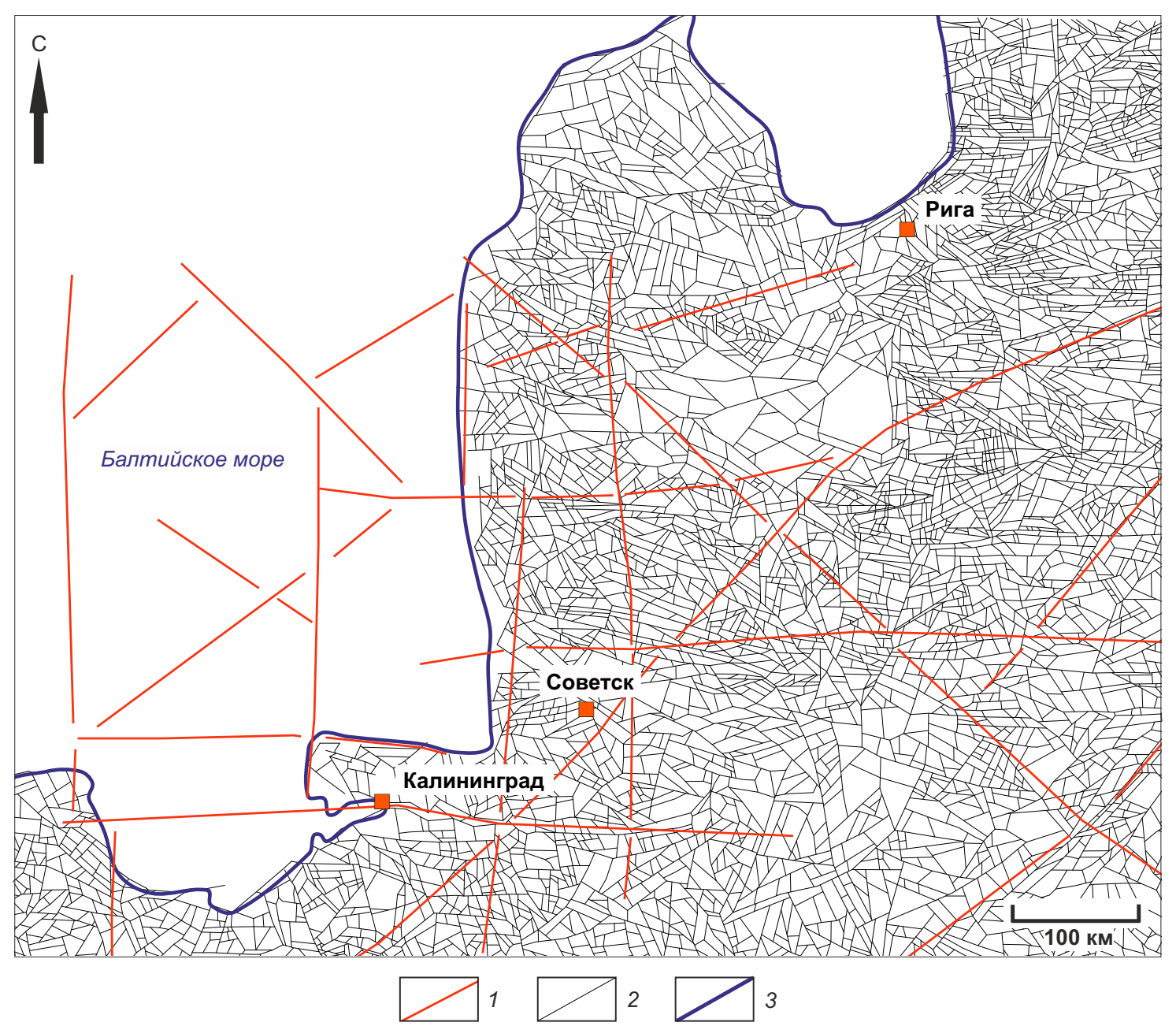

Рис. 1. Схема «слабых» зон и активных разломов Балтийской синеклизы. 1 - активные разломы по [Garetsky, Nesmeyanov, 2009]; 2 - «слабые» зоны; 3 - контуры береговой линии.

Fig. 1. Scheme of "weak" zones and active faults of the Baltic syneclise. 1 - active faults, after [Garetsky, Nesmeyanov, 2009 ]; 2 - "weak" zones; 3 - contours of the coastline.
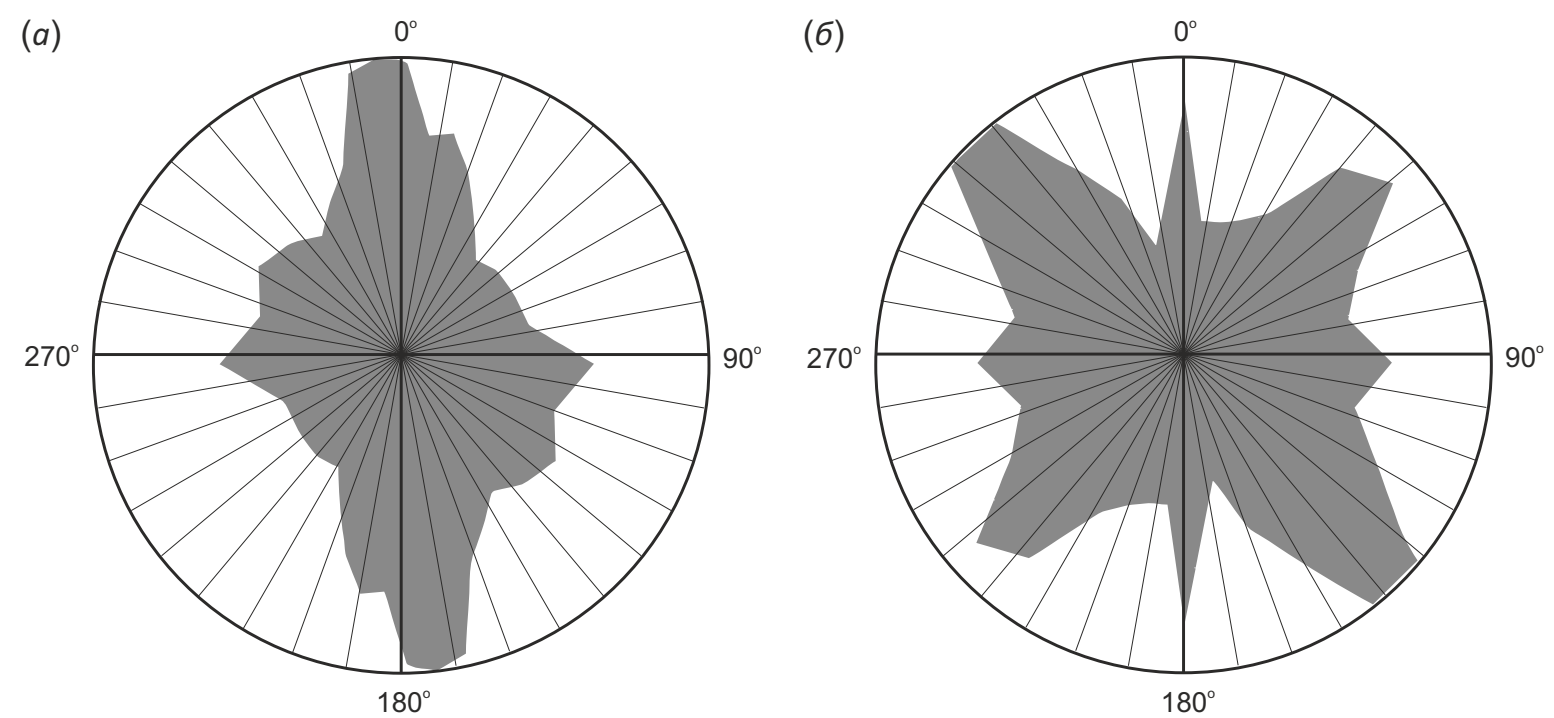

Рис. 2. Роза-диаграммы, иллюстрирующие закономерности ориентировки выделенных путем структурно-геоморфологического дешифрирования «слабых» зон Балтийской синеклизы (a) и севера Воронежской антеклизы (б).

Fig. 2. Rose diagrams illustrating the orientation patterns of the "weak" zones of the Baltic syneclise $(a)$ and the north of the Voronezh anteclise (б) identified by structural-geomorphological interpretation. 
глубинах (рис. 3) в пределах чехла; 2) расположение эпицентров землетрясений в чехле и фундаменте существенно различается, между плотностями эпицентров сейсмических событий чехла и фундамента существует слабая численная корреляция (коэффициент корреляции Пирсона 0.19); 3) повторяемость землетрясений в чехле и фундаменте описывается разными уравнениями.

Для фундамента соответствующее уравнение имеет вид:

$$
\begin{gathered}
\lg \left(\frac{N}{T}\right)=-0.44( \pm 0.07) M+0.35( \pm 0.25) ; \\
R_{c}=0.93 ; R^{2}=0.88
\end{gathered}
$$

где $N$ - количество землетрясений магнитуды $M, T-$ представленный период наблюдений в годах, $R_{c}-$ коэффициент корреляции, $R^{2}$ - коэффициент дисперсии. Для землетрясений осадочного чехла характерна следующая зависимость:

$$
\begin{gathered}
\lg \left(\frac{N}{T}\right)=-0.78( \pm 0.15) M+1.72( \pm 0.48) ; \\
R_{c}=0.94 ; R^{2}=0.89
\end{gathered}
$$

Приведенные численные показатели проходят проверку критериями Фишера и Стьюдента как для кристаллического фундамента $\left(F=40.23\right.$ и $t=6.34$ при $F_{\text {крит }}=$ $=6.6$ и $t_{\text {крит }}=2.57$ для уровня статистической значимости

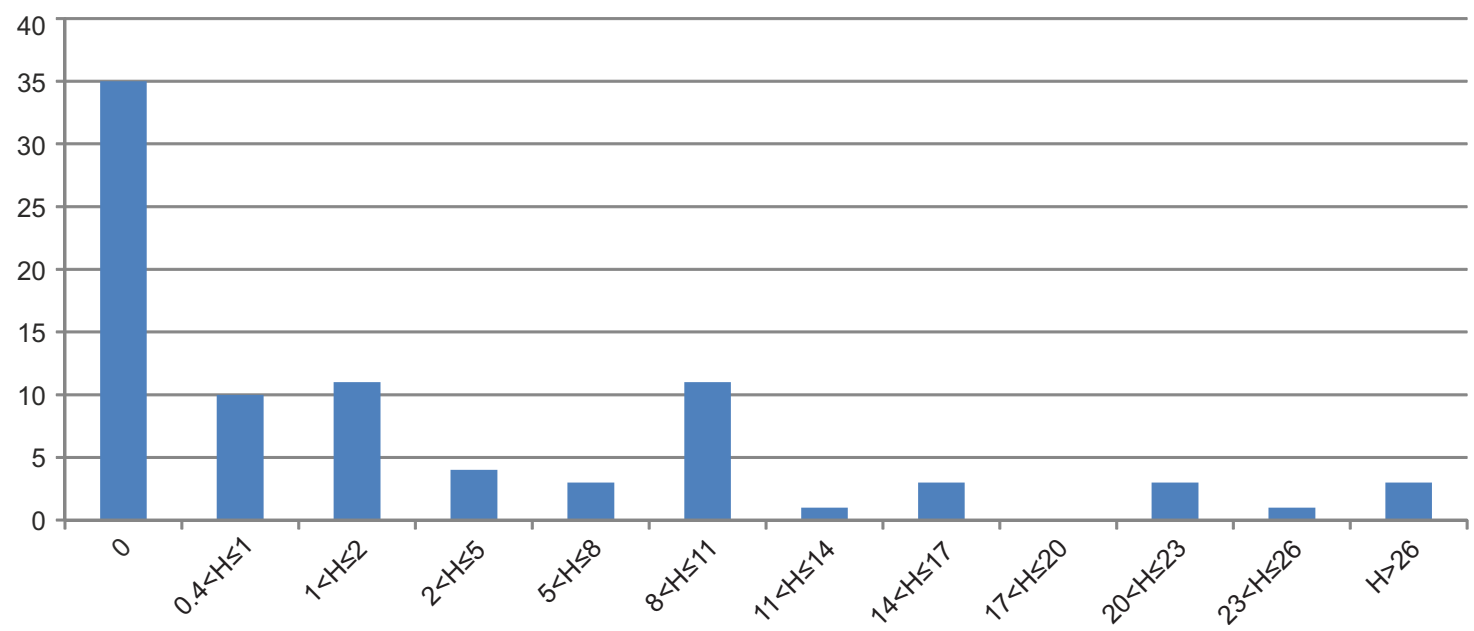

Рис. 3. Распределение гипоцентров землетрясений Балтийской синеклизы по глубинам (Н). По вертикальной оси отложены количества событий, по горизонтальной - интервалы глубин, км.

Fig. 3. Distribution of the hypocenters of the Baltic syneclise earthquakes by depth (H). The vertical axis shows the number of events, and the horizontal axis shows the depth intervals, $\mathrm{km}$.

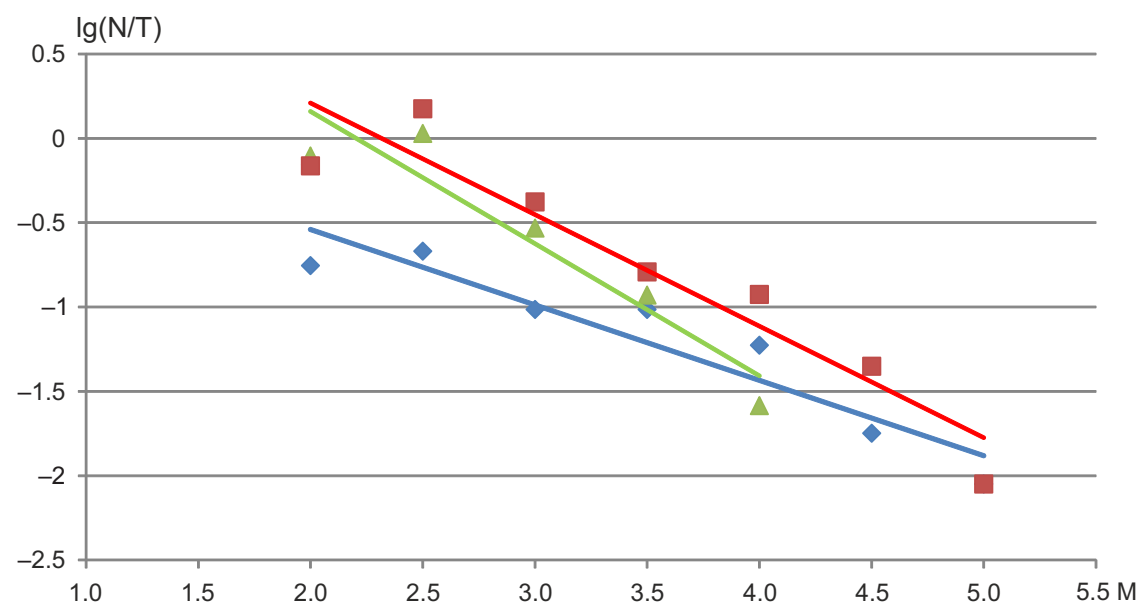

Рис. 4. Графики повторяемости землетрясений Балтийской синеклизы.

Синим цветом показан график повторяемости сейсмических событий в кристаллическом фундаменте, зеленым - в осадочном чехле, красным - общий график на Балтийскую синеклизу, составленный по табл. 1. $M$ - магнитуда землетрясений, $N$ - количество землетрясений магнитуды $M, T$ - представленный период наблюдений в годах.

Fig. 4. Earthquake recurrence curves for the Baltic syneclise.

The blue color shows an earthquake recurrence curve for the crystalline basement, green - for the sedimentary cover, red - a general curve for the Baltic syneclise, based on data in Table 1. $M$ - the magnitude of earthquakes, $N$ - the number of earthquakes of magnitude $M, T$ - the observation time period in years. 
$\alpha=0.05)$, так и для осадочного чехла ( $F=24.8$ и $t=4.98$ при $F_{\text {крит }}=10.12$ и $t_{\text {крит }}=3.18$ для уровня статистической значимости $\alpha=0.05)$, которые доказывают значимость зависимости $\lg \left(\frac{N}{T}\right)$ от $M$.

Повторяемость всех землетрясений Балтийской синеклизы описывается уравнением:

$$
\begin{gathered}
\lg \left(\frac{N}{T}\right)=-0.66( \pm 0.1) M+1.53( \pm 0.36) ; \\
R_{c}=0.94 ; R^{2}=0.89
\end{gathered}
$$

Эта зависимость также является значимой, поскольку проходит проверку критериями Фишера и Стьюдента $\left(F=43.43\right.$ и $t=6.59$ при $F_{\text {крит }}=6.6$ и $t_{\text {крит }}=2.57$ для уровня статистической значимости $\alpha=0.05$ ) (рис. 4).

Для моделирования новейшей геодинамики фундамента и чехла Балтийской синеклизы в качестве внешней нагрузки задавалось сдвиговое поле напряжения с азимутом простирания горизонтальной оси максимального сжатия $330^{\circ}$. Этот тип внешней нагрузки выбран по следующим соображениям: 1) он согласуется с решением фокального механизма очага Калининградского землетрясения 21.09.2004 г. с магнитудой $M=4.8$, произошедшего на глубине 7-10 км в районе Самбийского полуострова [Rogozhin et al., 2014b]; 2) большая часть спрямленных участков эрозионной сети, выделенных путем автоматизированного анализа ЦМР в программе LESSA, простирается в северо-западных румбах (рис. 5). Поскольку эти линеаменты могут образовываться в результате растягивающих напряжений [Panina et al., 2017], существуют основания предположить, что ось растяжения на территории Балтийской синеклизы ориентирована ортогонально доминирующему направлению их простирания.

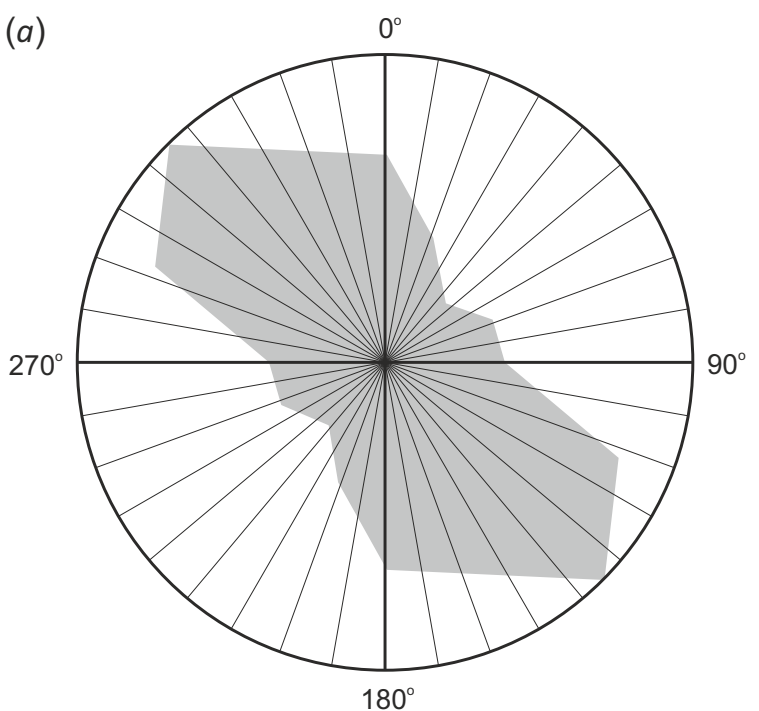

Наиболее вероятной причиной новейших деформаций синеклизы представляется гляциоизостатическое поднятие Балтийского щита [Keiding et al., 2015], приводящее к возникновению сдвиговой обстановки на его периферии [Sentsov, 2019; Sentsov, Agibalov, 2021].

Конфигурация активных разломов, использовавшихся для разработки компьютерной модели, показана на рис. 1. Они были выделены по комплексу геолого-геоморфологических признаков С.А. Несмеяновым и O.A. Воейковой [Garetsky, Nesmeyanov, 2009]. В peзультате моделирования установлена численная корреляция между энергией землетрясений, интерполированной на всю территорию Балтийской синеклизы, и вероятностью формирования трещин отрыва: коэффициент корреляции Пирсона между упомянутыми параметрами составляет 0.58 для осадочного чехла и 0.42 для фундамента (рис. 6, 7, 8, 9).

Эти данные позволяют предположить, что эпицентры самых сильных землетрясений приурочены к участкам концентрации растягивающих напряжений. Кроме того, установлено, что все эпицентры сейсмических событий расположены в пределах областей возможного формирования новых разрывов малой протяженности, что свидетельствует в пользу достоверности предложенной компьютерной модели. Однако эти области занимают значительную часть площади Балтийской синеклизы, из-за чего не могут использоваться для выделения зон ВОЗ. Контуры показанных на рис. 10 зон В03 проведены по данным о пространственном распределении эпицентров землетрясений.

Три зоны В03 (Береговая, Южно-Калининградская и Калининградская) расположены в пределах фундамента, пять - в осадочном чехле (Вильнюсская, РижскоСоветская, Рижская, Советско-Балтийская, Гданьская). (б)

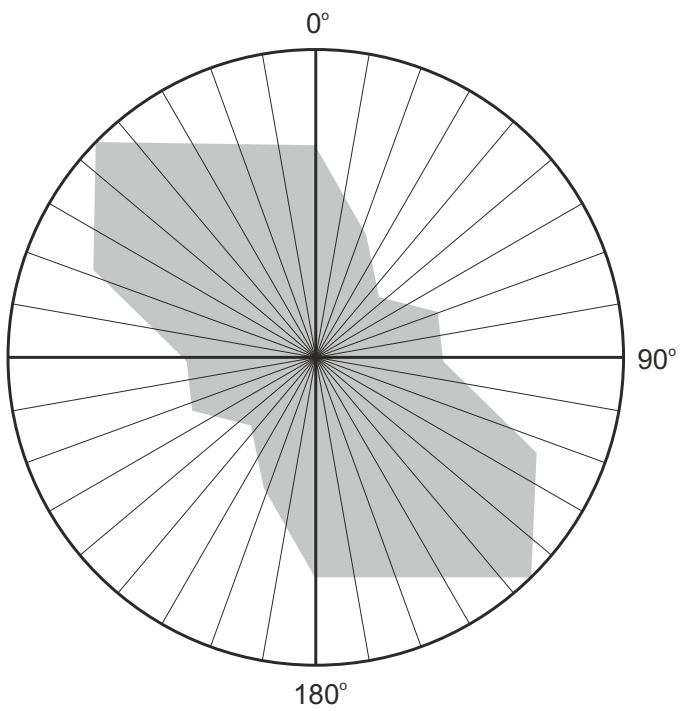

Рис. 5. Роза-диаграммы, иллюстрирующие ориентировки линеаментов-«штрихов», выделенных путем автоматизированного дешифрирования ЦМР Балтийской синеклизы $(a)$ и северной части Воронежской антеклизы (б).

Fig. 5. Rose diagrams illustrating the orientations of the lineaments identified by automated DEM interpretation for the Baltic syneclise (a) and the northern part of the Voronezh anteclise (б). 


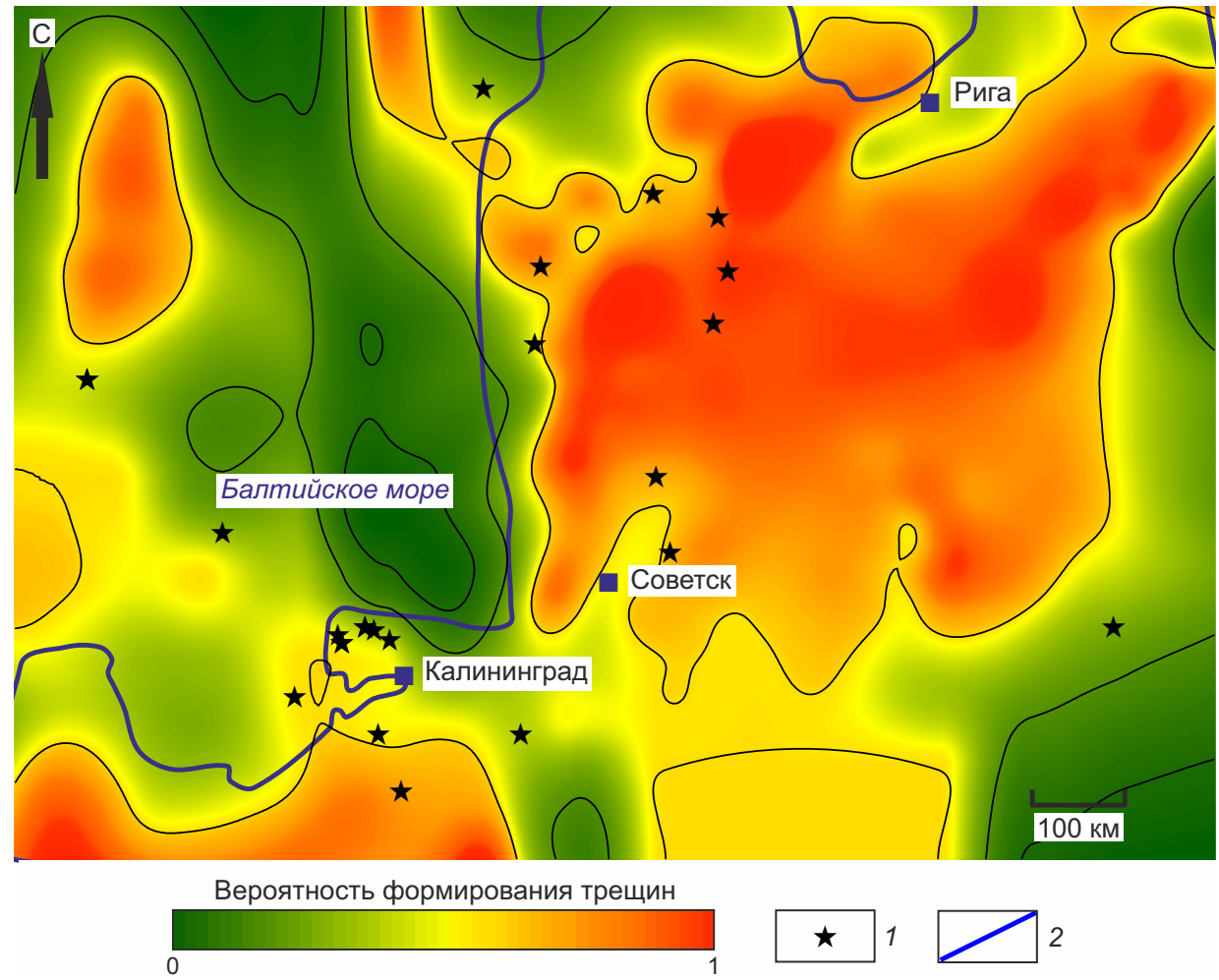

Рис. 6. Схема вероятности формирования трещин отрыва в фундаменте Балтийской синеклизы. 1 - эпицентры землетрясений в фундаменте Балтийской синеклизы; 2 - контуры береговой линии.

Fig. 6. Scheme of the probability of occurrence of ruptures in the basement of the Baltic syneclise. 1 - epicenters of earthquakes in the foundation of the Baltic syneclise; 2 - contours of the coastline.

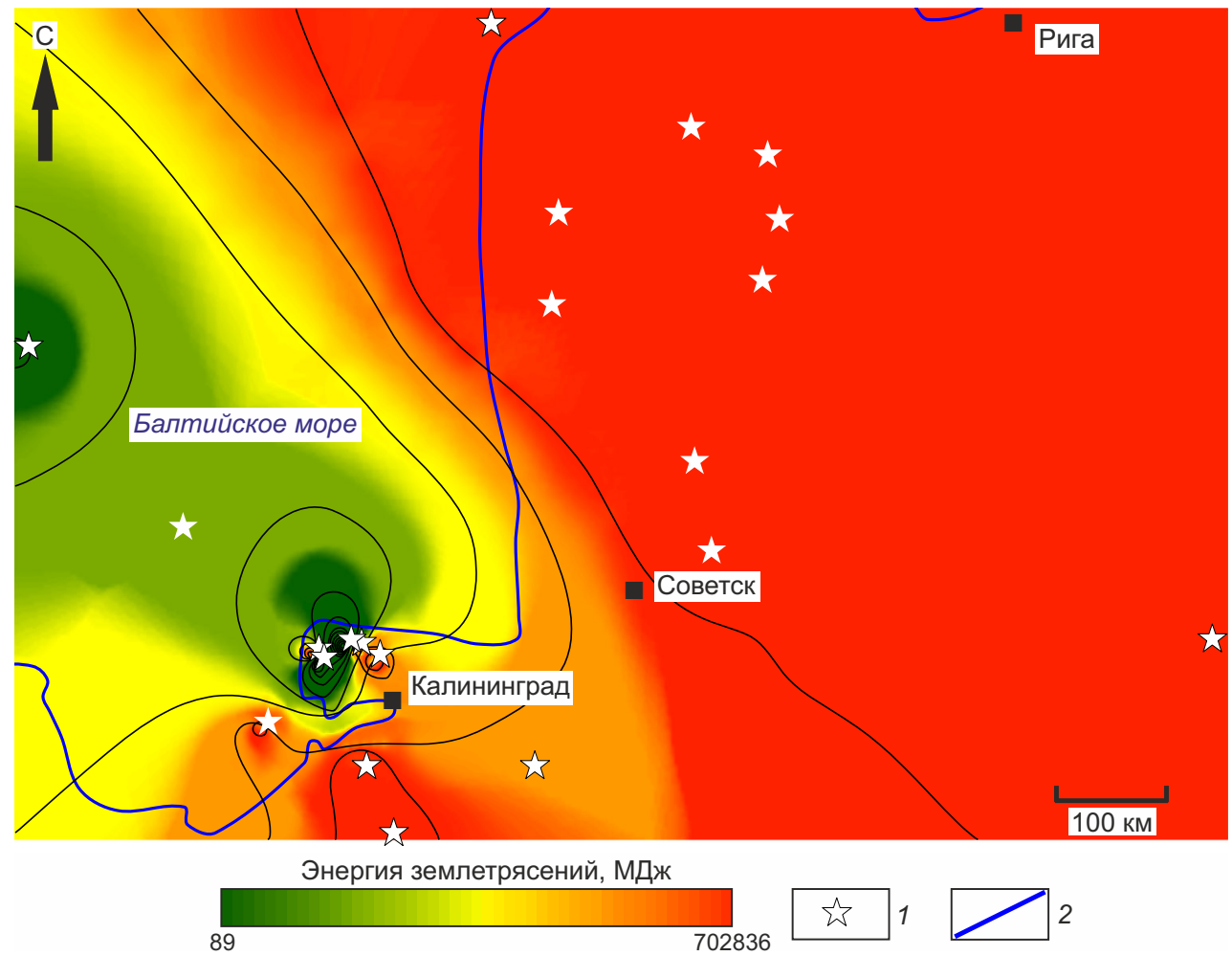

Рис. 7. Схема энергии землетрясений в фундаменте Балтийской синеклизы. 1 - эпицентры землетрясений в фундаменте Балтийской синеклизы; 2 - контуры береговой линии.

Fig. 7. Scheme of earthquake energies in the basement of the Baltic syneclise. 1 - epicenters of earthquakes in the basement of the Baltic syneclise; 2 - contours of the coastline. 


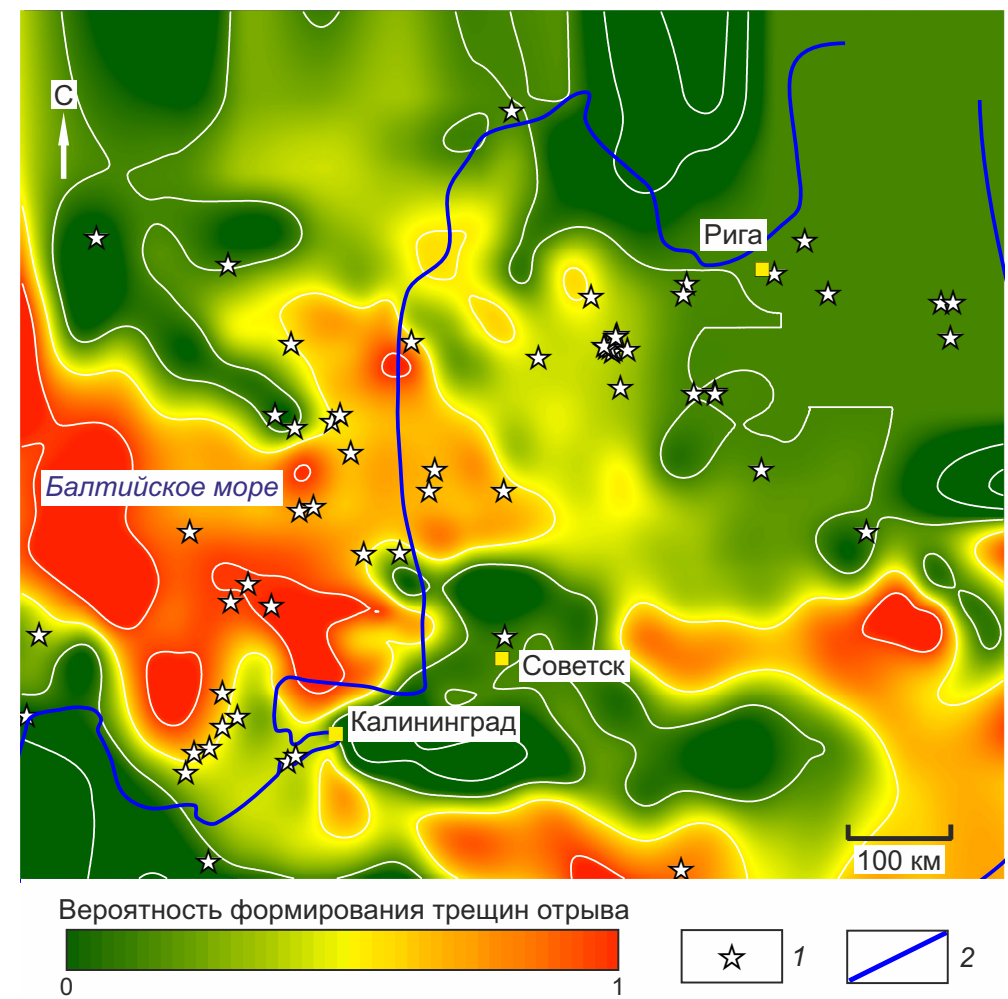

Рис. 8. Схема вероятности формирования трещин отрыва в осадочном чехле Балтийской синеклизы. 1 - эпицентры землетрясений в осадочном чехле Балтийской синеклизы; 2 - контуры береговой линии.

Fig. 8. Scheme of the probability of occurrence of ruptures in the sedimentary cover of the Baltic syneclise. 1 - earthquake epicenters in the sedimentary cover of the Baltic syneclise; 2 - contours of the coastline.

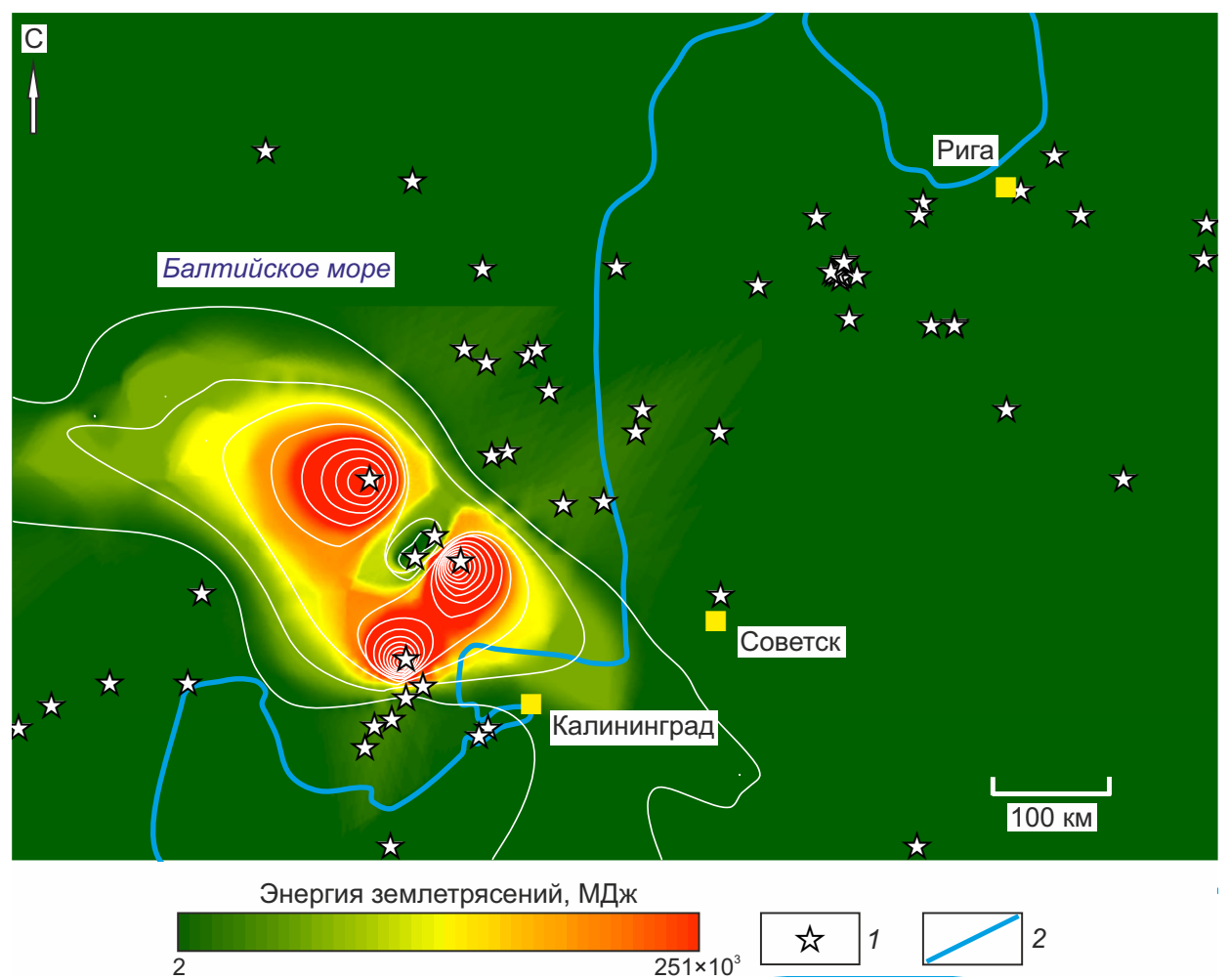

Рис. 9. Схема энергии землетрясений в осадочном чехле Балтийской синеклизы. 1 - эпицентры землетрясений в осадочном чехле Балтийской синеклизы; 2 - контуры береговой линии.

Fig. 9. Scheme of earthquake energies in the sedimentary cover of the Baltic syneclise. 1 - earthquake epicenters in the sedimentary cover of the Baltic syneclise; 2 - contours of the coastline. 


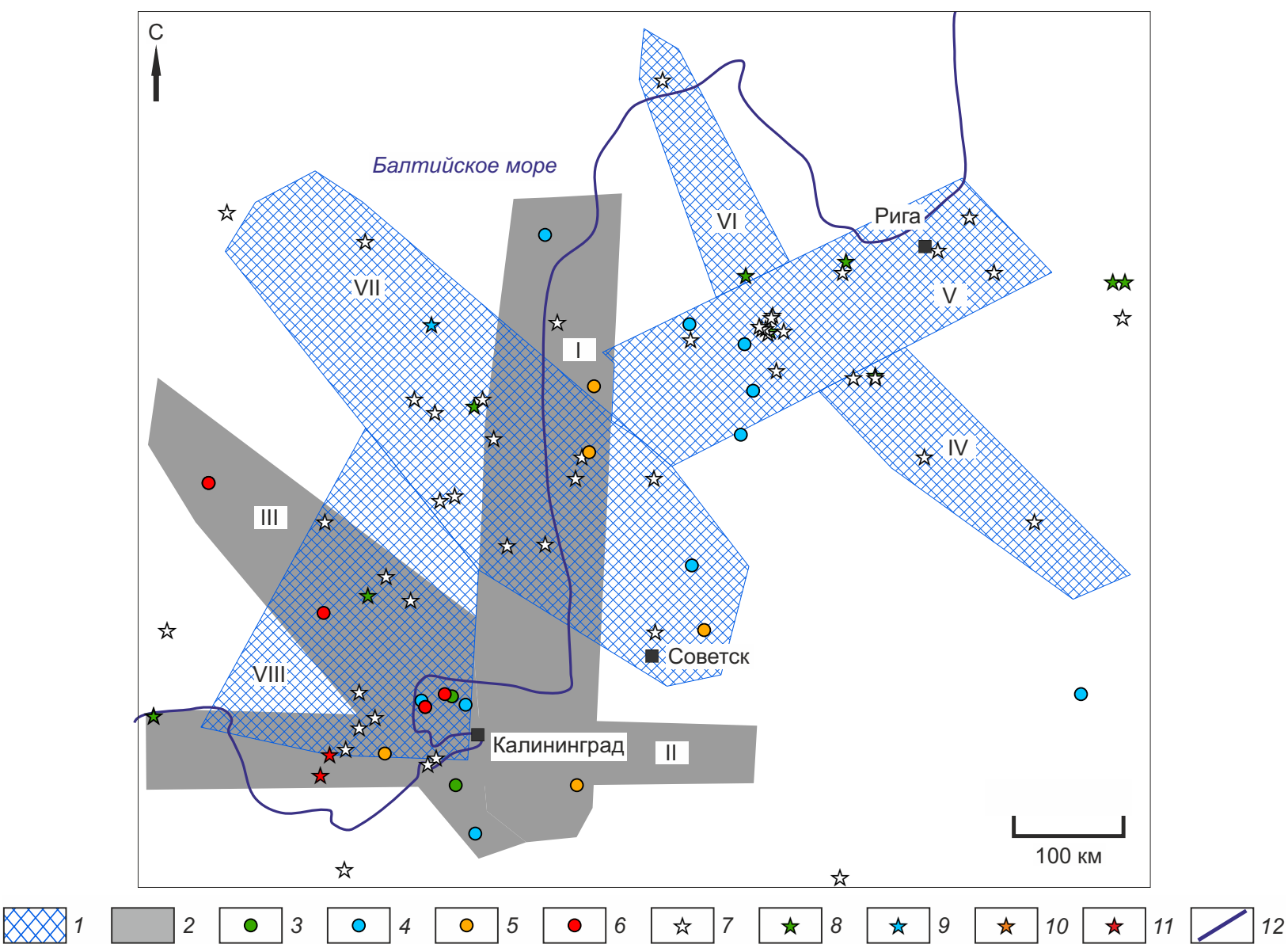

Рис. 10. Схема зон ВОЗ Калининградской области и сопредельных территорий.

1-2 - зоны ВОЗ: 1 - в осадочном чехле, 2 - в фундаменте; 3-6 - эпицентры землетрясений в фундаменте с магнитудой: 3 $1-2,4-2-3,5-3-4,6-4-5 ; 7-11$ - эпицентры землетрясений в чехле с магнитудой: 7- 0-1, 8-1-2, 9-2-3, 10 - 3-4, 11 - 4-5; 12 - контуры береговой линии. Римскими цифрами обозначены зоны ВОЗ: I - Береговая, II - Южно-Калининградская, III Калининградская, IV - Вильнюсская, V - Рижско-Советская, VI - Рижская, VII - Советско-Балтийская, VIII - Гданьская.

Fig. 10. Scheme of source zones in the Kaliningrad region and adjacent territories.

1-2 - source zones: 1 - in the sedimentary cover, 2 - in the basement; 3-6 - epicenters of basement earthquakes with magnitudes of: $3-1-2,4-2-3,5-3-4,6-4-5 ; 7-11$ - epicenters of earthquakes in the cover with magnitudes of: 7-0-1, 8-1-2, 9-2-3, 10-3-4, $11-4-5 ; 12$ - contours of the coastline. Roman numerals indicate source zones: I - Beregovaya, II - South Kaliningrad, III - Kaliningrad, IV - Vilnius, V - Riga - Sovetsk, VI - Riga, VII - Sovetsk - Baltic, VIII - Gdansk.

Табл. 3. Максимальные магнитуды землетрясений в зонах В0З Балтийской синеклизы

Table 3. Maximum earthquake magnitudes in the source zones of the Baltic syneclise

\begin{tabular}{llc}
\hline № & Название & $M_{\max }$ \\
\hline I & Береговая & 4.5 \\
II & Южно-Калининградская & 4.5 \\
III & Калининградская & 5.5 \\
IV & Вильнюсская & 3.4 \\
V & Рижско-Советская & 3.5 \\
VI & Рижская & 3.3 \\
VII & Советско-Балтийская & 4.1 \\
VII & Гданьская & 4.7 \\
\hline
\end{tabular}

Максимальные магнитуды землетрясений в этих зонах указаны в табл. 3.

В целом конфигурация выделенных зон В03 согласуется с результатами работ [Rogozhin et al., 2014a; Garetsky, Nesmeyanov, 2009]. К Южно-Калининградской, Калининградской и Гданьской зонам ВОЗ приурочены активные разрывные нарушения 3-го порядка; к Вильнюсской, Рижско-Советской и Рижской - активные разломы 2-го порядка (мелкоблоковые погребенные структуры Шауляй-Гомельская шовно-разрывная и Лиепайско-Псковская шовно-антиклинальная) [Garetsky, Nesmeyanov, 2009].

\section{4. АНАЛИЗ НОВЕЙШЕЙ ГЕОДИНАМИКИ СЕВЕРНОЙ ЧАСТИ ВОРОНЕЖСКОЙ АНТЕКЛИЗЫ}

Воронежская антеклиза располагается в пределах нескольких крупных неотектонических зон: Смоленской, Днепрово-Деснинской, Среднерусской, Окско-Донской 
и Приволжской [Tregub, 2005; Ezhova et al., 2010]. Выделенные в новейшей структуре Днепрово-Деснинский, Среднерусский и Окско-Донской блоки являются отражением Брянского, Курского и Хоперского мегаблоков кристаллического фундамента, а линейные впадины новейшего этапа приурочены к региональным разрывным нарушениям [Sokolov, 2013]. Средние амплитуды восходящих неотектонических движений пяти перечисленных неотектонических зон составляют 75100 м, 75 м, 150 м, 90 м и 100-200 м соответственно [Tregub, 2001]. Рассмотренная в статье северная часть Воронежской антеклизы соответствует северной и центральной области Среднерусского поднятия и ОкскоДонскому прогибу [Tregub, 2001]. Выбор северной части Воронежской антеклизы в качестве объекта исследования обусловлен следующими соображениями: 1) в ее пределах достаточно часто происходят сейсмические события с $M \geq 3$; 2) в неотектоническом отношении она представляет собой отдельный сегмент, ограниченный со всех сторон геодинамически активными зонами (Сеймской, Верхнеокской, Юхнов-Серпуховской, Лосевской) [Makarova et al., 2016].

Для выбранного участка Воронежской антеклизы нами проведено структурно-геоморфологическое дешифрирование, позволившее установить основные особенности пространственного рисунка «слабых» зон, нарушающих новейший структурный план. Выделены «слабые» зоны субмеридиональной, диагональной (северо-западной и северо-восточной) и субширотной ориентировки (в порядке уменьшения значимости), величины $m_{g}$ и $M_{g}$ составляют 92.4 и $187.9^{\circ}$ соответственно (см. рис. 2). Ўстановлено, что ряд разломов [State Geological Map..., 2015] находит прямое отражение в релье$\phi$ e [Zaitsev et al., 2016, 2017; Panina et al., 2017]. Этот факт является одним из аргументов в пользу их геодинамической активности. Данные о конфигурации таких разломов были использованы при проведении компьютерного моделирования. Сходство ориентировок выделенных в программе LESSA линеаментов«штрихов» Балтийской синеклизы и северной части Воронежской антеклизы позволило предположить, что последняя также развивается в сдвиговой обстановке при ориентировке оси сжатия в северо-западном направлении. Предположительно, этот тип внешней нагрузки обусловлен влиянием горно-складчатых сооружений Урала [Zykov, 2004; Zykov, Poleshchuk, 2016] и Кавказа [Корр, 2000]. Согласно этим работам, кавказский сегмент Альпийско-Гималайского пояса оказывает воздействие на Донецкую складчатую зону, испытывающую сжатие. Это сжатие передается как перпендикулярно фронту, так и вдоль Днепрово-Донецкого авлакогена, передавая напряжения в «тело платформы, образовывая своеобразный клин» [Zykov, 2004]. В то же время Аравийский микроконтинент, двигающийся в северо-восточном направлении, оказывает влияние на складчатое сооружение Кавказа, которое является для него краевой зоной. Решения очагов землетрясений в пределах Кавказа показывают, что большая часть сейсмических событий реализуется в сжимающем поле напряжения с северо-восточной ориентировкой осей сжатия. Таким образом, в рамках геокинематической модели, предложенной в работе [Корр, 2004], Кавказ передает напряжения, полученные от Аравийской плиты. Влияние Уральского орогена может быть выражено в меньшей степени, так как он находится в «условиях косого сближения Восточно-Европейской и Западно-Сибирской платформ», и может ослабляться под действием Каспийской геодинамической системы, основное место в которой занимает Прикаспийский прогиб [Makarova et al., 2016].

Сводный сейсмологический каталог рассматриваемой области включает информацию о 234 землетрясениях. В северной части большинство эпицентров землетрясений приурочено к речным долинам, а в южной к сводовым зонам новейших поднятий, выделенных при структурно-геоморфологическом анализе. Эти данные согласуются с ранее полученными результатами других исследователей. Например, в работе [Ezhova et al., 2010] отмечена взаимосвязь эпицентров землетрясений с линейными неотектоническими прогибами неоген-четвертичного возраста. Повторяемость землетрясений в пределах северной части Воронежской антеклизы описывается уравнением (рис. 11):

$$
\begin{gathered}
\lg \left(\frac{N}{T}\right)=-0.87( \pm 0.13) M+1.93( \pm 0.27) ; \\
R_{c}=0.96 ; R^{2}=0.93 .
\end{gathered}
$$

Эта зависимость проходит проверку критерием Фишера $\left(F=44.77\right.$ при $F_{\text {крит }}=10.13$ для уровня статистической значимости $\alpha=0.05$ ), что свидетельствует о ее достоверности.

Основным результатом компьютерного моделирования является схема областей возможного формирования новых разрывов малой протяженности («Fracture regions») (рис. 12). Наряду со схемой плотности эпицентров землетрясений (рис. 13), она использована для выделения зон ВОЗ, поскольку области формирования новых разрывов занимают 39 \% всей площади северной части Воронежской антеклизы, при этом в их пределах расположен 71 \% эпицентров землетрясений.

Отметим, что при присвоении участкам, на которых могут формироваться новые разрывы малой протяженности, единичных значений, а всем остальным нулевых достигается численная корреляция между параметром «Fracture regions» и плотностью эпицентров землетрясений (коэффициент корреляции Пирсона 0.41). Выделенные нами шесть зон ВОЗ и максимальные магнитуды сейсмических событий в их пределах рассмотрены в табл. 4.

Часть зон ВОЗ приурочена к тектоническим структурам: Пачелмская зона соответствует одноименному авлакогену, Северо-Воронежская - центральной части Лосевской шовной зоны, ограниченной разрывными нарушениями первого порядка [Sharov et al., 2007], Липецкая зона приурочена к границе двух новейших поднятий - Лебедянь-Липецкого и Орловско-Тульского 


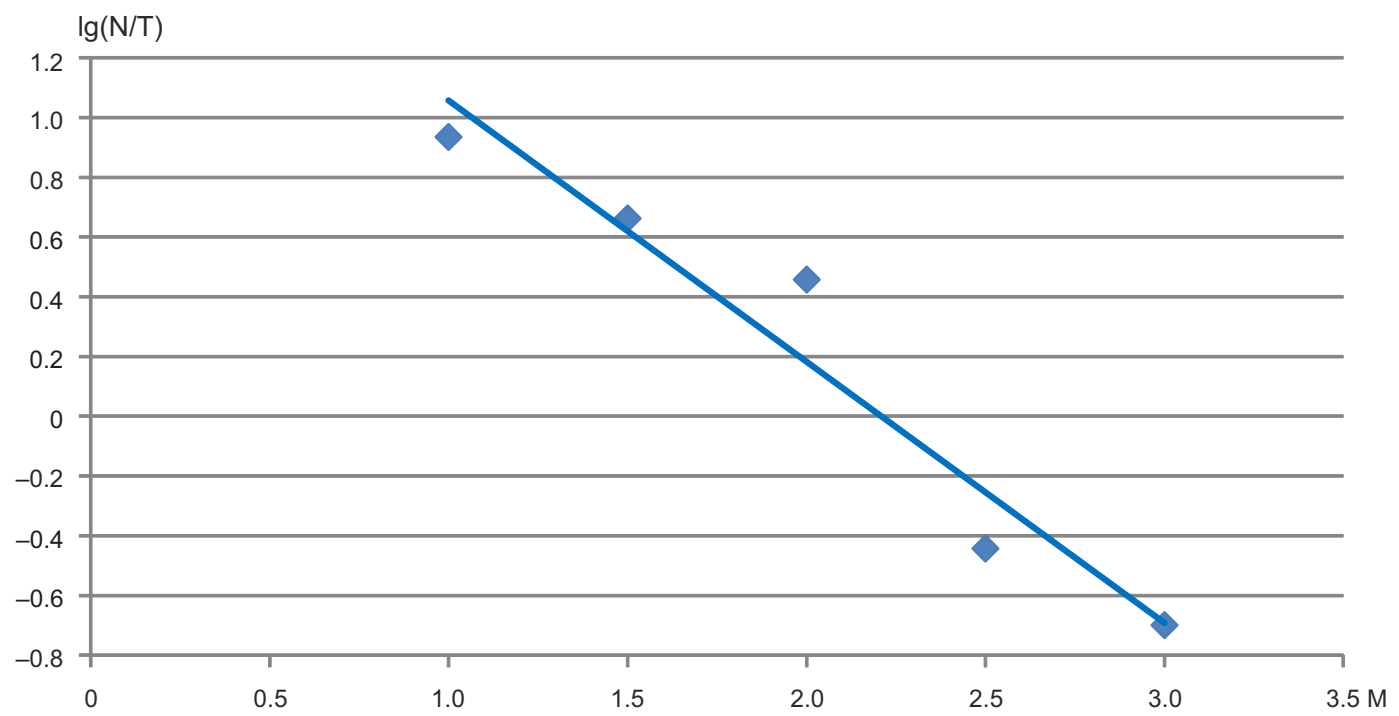

Рис. 11. График повторяемости землетрясений северного склона Воронежской антеклизы, составленный по табл. 2 . $M-$ магнитуда землетрясений, $N$ - количество землетрясений магнитуды $M, T$ - период наблюдений в годах.

Fig. 11. The earthquake recurrence curve for the northern slope of the Voronezh anteclise, based on data in Table 2. $M$ is the magnitude of the earthquakes, $N$ - number of earthquakes of magnitude $M, T$ - observation period in years.
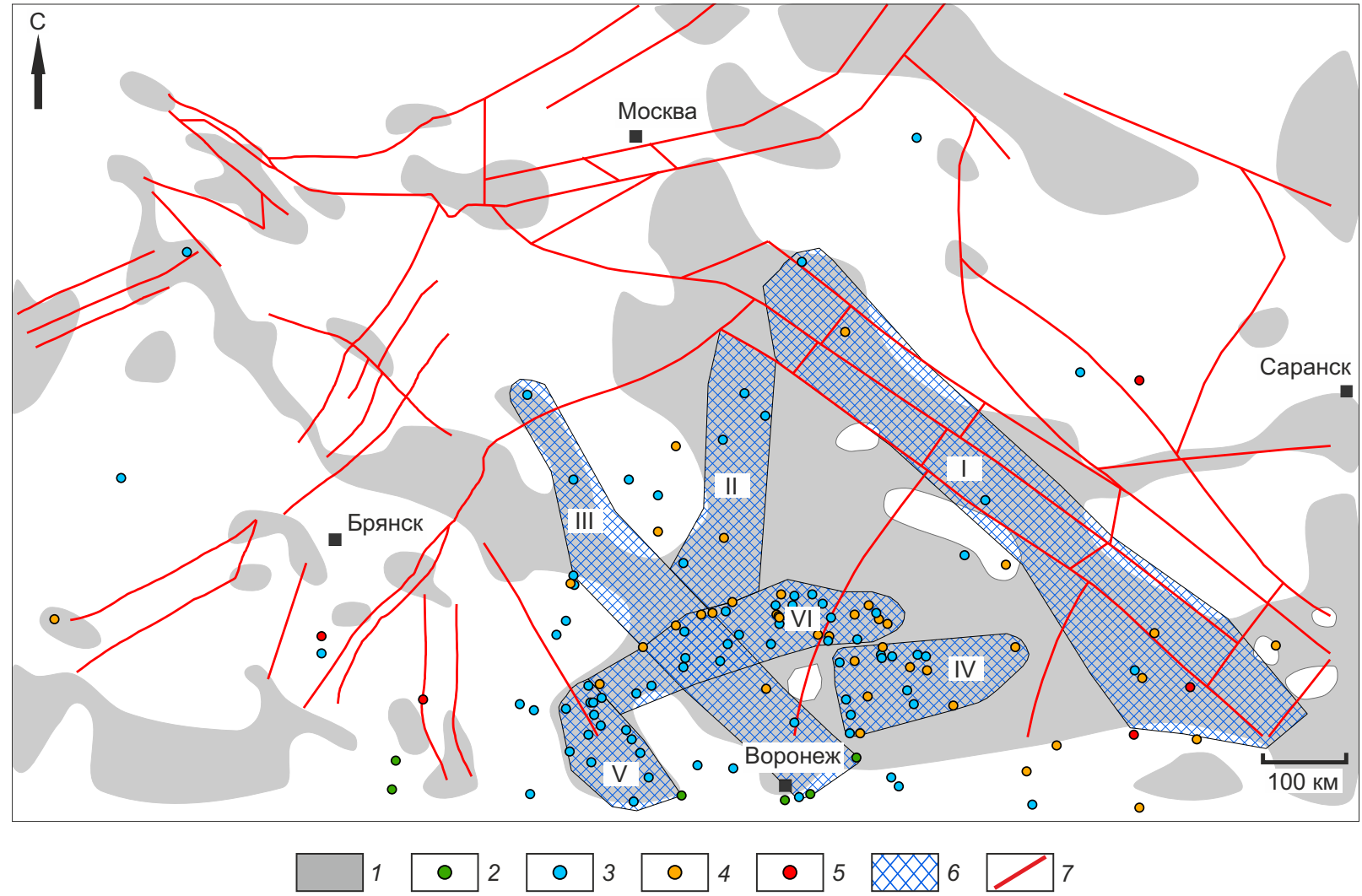

Рис. 12. Схема областей возможного формирования новых разрывов малой протяженности северной части Воронежской антеклизы.

1 - области возможного формирования новых разрывов малой протяженности; 2-5 - эпицентры землетрясений с магнитудой: 2 - 0-1, 3 - 1-2, 4 - 2-3, 5 - 3-4; 6 - зоны В03: I - Пачелмская, II - Липецкая III - Калужско-Елецкая, IV - Северо-Воронежская, V - Тербунская, VI - Курско-Липецкая; 7 - предполагаемые активные разломы, использованные для построения компьютерной модели новейшей геодинамики.

Fig. 12. Scheme of the areas of the probable new small-extent rupture occurrence in the northern part of the Voronezh anteclise. 1 - areas of the probable new small-extent rupture occurrence; 2-5 - epicenters of earthquakes with magnitudes: 2-0-1,3-1-2, 42-3, 5 - 3-4; 6 - source zones: I - Pachelma, II - Lipetsk, III - Kaluga-Yelez, IV - Northern Voronezh, V - Terbunskaya, VI - Kursk-Lipetsk; 7 - inferred active faults used to construct a computer neogeodynamic model. 


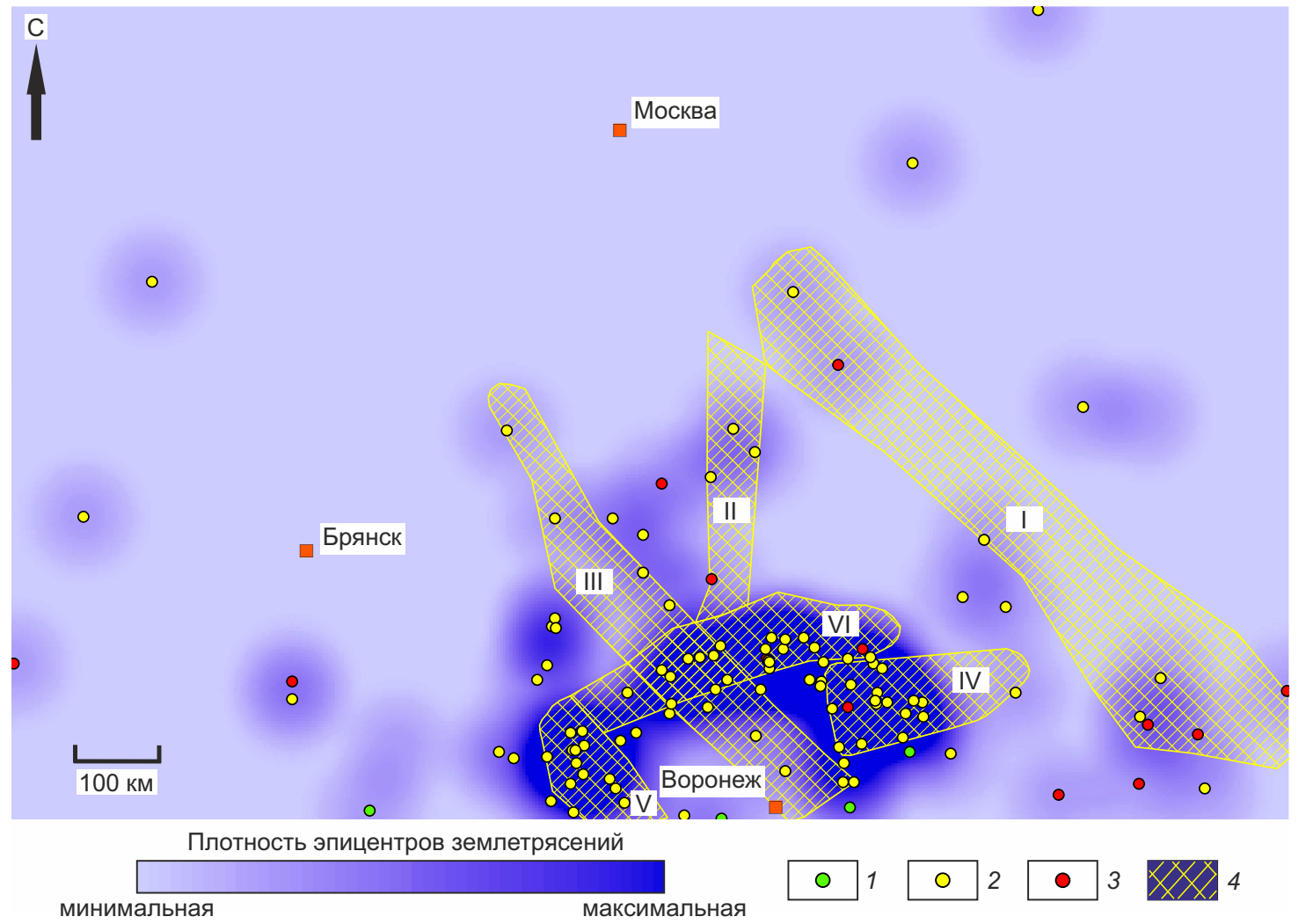

Рис. 13. Схема плотности эпицентров землетрясений северной части Воронежской антеклизы.

1-4 - эпицентры землетрясений с магнитудой: 1 - 0-1, 2 - 1-2, 3 - 2-3, 4- 3-4; 5 - зоны ВОЗ: I - Пачелмская, II - Липецкая, III Калужско-Елецкая, IV - Северо-Воронежская, V - Тербунская, VI - Курско-Липецкая.

Fig. 13. Scheme of the density of earthquake epicenters in the northern part of the Voronezh anteclise.

1-4 - epicenters of earthquakes with magnitudes: 1 - 0-1, $2-1-2,3-2-3,4-3-4$; 5-source zones: I - Pachelma, II - Lipetsk, III Kaluga-Yelez, IV - Northern Voronezh, V - Terbunskaya, VI - Kursk-Lipetsk.

Табл. 4. Максимальные магнитуды землетрясений в зонах В03 северной части Воронежской антеклизы

Table 4. Maximum earthquake magnitudes in the source zones of the northern part of the Voronezh anteclise

\begin{tabular}{llc}
\hline № & Название & Mmax \\
\hline I & Пачелмская & 3.8 \\
II & Липецкая & 2.7 \\
III & Калужско-Елецкая & 2.7 \\
IV & Северо-Воронежская & 2.7 \\
V & Тербунская & 2.4 \\
VI & Курско-Липецкая & 3.2 \\
\hline
\end{tabular}

[Sokolov, 2013]. Тербунскую зону можно соотнести с локальными поднятиями в пределах Кшень-Оскольского блока 3-го ранга (Среднерусский сегмент Воронежской антеклизы) [Tregub, 2001]. Расположение Липецкой, Тербунской, Курско-Липецкой, Пачелмской и Калужско-Елецкой зон ВОЗ хорошо согласуется с пространственным рисунком геодинамически активных зон, выделенных в работе [Efremenko, 2011].

\section{5. СРАВНИТЕЛЬНЫЙ АНАЛИЗ}

Сравнительный анализ новейшей геодинамики Балтийской синеклизы и северной части Воронежской антеклизы заключается в сопоставлении полученных нами новых данных с целью установления сходства и различий проявления неотектонических процессов в этих районах.

Сопоставление приведенных на рис. 2 роза-диаграмм показало, что на исследуемых территориях преобладают «слабые» зоны ортогональной системы, что подтверждается схожестью средних круговых значений $\left(m_{g}=96.9^{\circ}\right.$ и $\left.92.4^{\circ}\right)$ и выборочных мод $\left(M_{g}=186.0^{\circ}\right.$ и $\left.187.9^{\circ}\right)$. Вероятно, они связаны с планетарной трещиноватостью. В то же время на территории Воронежской антеклизы достаточно четко представлено диагональное направление, в то время как на Балтийской синеклизе оно выражено слабее. Этот факт объясним разной геометрией древних разломов, активизированных на новейшем этапе.

Методом автоматизированного анализа ЦМР установлена общая геоморфологическая особенность, заключающаяся в преобладании спрямленных участков эрозионной сети северо-западного простирания. По нашему мнению, она связана с тем, что оба рассматриваемых района на новейшем этапе развиваются в 
сдвиговой обстановке при ориентировке оси сжатия в северо-западных румбах.

Анализируя графики повторяемости землетрясений двух регионов, можно заметить, что тангенсы углов их наклона схожи $(-0.66$ и -0.87 для Балтийской синеклизы и северного склона Воронежской антеклизы соответственно). Более крутой наклон графика Воронежской антеклизы свидетельствует о большей повторяемости землетрясений низких магнитуд по сравнению с высокомагнитудными. Такие сейсмические события происходят здесь чаще, чем в пределах Балтийской синеклизы. Из-за схожести наклона графиков мы предполагаем, что сейсмичность обоих регионов вызвана однотипным полем напряжений, но источники напряжений различны. Различие графиков заключается в том, что на территории Балтийской синеклизы чаще возможны относительно высокомагнитудные $(M>4.5)$ события. На наш взгляд, это отличие связано с тем, что Балтийская синеклиза находится ближе к Балтийскому щиту, напряжения от которого передаются ей, в то время как Кавказский и Уральский орогены находятся на значительном удалении от Воронежской антеклизы, что не позволяет им оказывать более активное воздействие. В то же время горно-складчатое сооружение Кавказа более активно по сравнению с Балтийским щитом (что подтверждается энергией землетрясений этих регионов), в результате чего он может влиять на структуры на большем удалении, чем щит.

\section{6. ЗАКЛЮЧЕНИЕ}

Таким образом, анализ новейшей геодинамики позволил достичь следующих результатов.

1. Установлено, что на новейшем этапе Балтийская синеклиза и Воронежская антеклиза развиваются в сдвиговом поле напряжений при ориентировке оси максимального сжатия в северо-западном направлении. Этот тип внешней нагрузки обусловливает сходство ориентировок спрямленных участков эрозионной сети, выделенных путем автоматизированного анализа ЦМР.

2. Разработаны компьютерные модели новейшей геодинамики, объясняющие ряд особенностей сейсмичности обоих рассматриваемых районов активизацией выраженных в рельефе разрывных нарушений фундамента ВЕП.

3. Показан разный характер сейсмичности в чехле и фундаменте Балтийской синеклизы; установлена меньшая степень сейсмотектонической активности этой структуры по сравнению с северной частью Воронежской антеклизы.

4. Предложены схемы зон ВОЗ.

\section{7. ЛИТЕРАTУРA / REFERENCES}

Agibalov A.O., Zaytsev V.A., Sentsov A.A., Devyatkina A.S., 2017. Assessment of the Influence of Modern Crustal Movements and the Recently Activated Precambrian Structural Plan on the Relief of the Lake Ladoga Region (The Southeastern Baltic Shield). Geodynamics \& Tectonophysics 8 (4),
791-807 (in Russian) [Агибалов А.О., Зайцев В.А., Сенцов А.А., Девяткина А.С. Оценка влияния современных движений земной коры и активизированного в новейшее время докембрийского структурного плана на рельеф Приладожья (юго-восток Балтийского щита) // Геодинамика и тектонофизика. 2017. Т. 8. № 4. С. 791-807]. https://doi.org/10.5800/GT-2017-8-4-0317.

Analysis Package Reservoir Modelling System (RMS), 2012. User Guide. Available from: www.geodisaster.ru/ index.php?page=uchebnye-posobiya-2 (Last Accessed December 1, 2019).

Efremenko M.A., 2011. The Present-Day Geodynamically Active Zones of the Voronezh Crystalline Massif from the Geological, Geophysical and Seismogeological Data. Brief PhD Thesis (Candidate of Geology and Mineralogy). Moscow, 23 p. (in Russian) [Ефременко М.А. Современные геодинамически активные зоны Воронежского кристаллического массива по геологическим, геофизическим и сейсмологическим данным: Автореф. дис. ... канд. геол.-мин. наук. М., 2011. 23 с.].

Ezhova I.T., Efremenko M.A., Tregub A.I., 2010. Seismic Activity and Neotectonics of the Voronezh Crystalline Massif. Proceedings of Voronezh State University. Series: Geology 1, 229-232 (in Russian) [Ежова И.Т., Ефременко М.А., Трегуб А.И. Сейсмическая активность и неотектоника Воронежского кристаллического массива // Вестник ВГУ. Серия: Геология. 2010. № 1. С. 229-232].

Garetsky R.G., Aizberg R.E., Karabanov A.K., Palienko V.P., Sliaupa A.I., 1999. Neotectonics and Neogeodynamics of Central Europe. Geotectonics 33 (5), 343-352.

Garetsky R.G., Nesmeyanov S.A. (Eds), 2009. Seismotectonics of Plate-Ancient Platforms Glaciated During the Quaternary. Kniga i Biznes, Moscow, 288 p. (in Russian) [Сейсмотектоника плит древних платформ в области четвертичного оледенения / Ред. Р.Г. Гарецкий, С.А. Несмеянов. М.: Книга и Бизнес, 2009. 288 с.].

Gutenberg B., Richter C.F., 1956. Earthquake Magnitude, Intensity, Energy and Acceleration (Second Paper). Bulletin of the Seismological Society of America 46 (2), 105-145. https://doi.org/10.1785/BSSA0460020105.

Guterch B., Levandowska-Marciniak H., 2002. Seismicity and Seismic Hazard in Poland. Folia Quanternaria 73, 85-99.

Ivanov S.N., Ivanov K.S., 2018. Rheological Model of Earth's Crust (Model of Third Generation). Lithosphere 18 (4), 500519 (in Russian) [Иванов С.Н., Иванов К.С. Реологическая модель строения земной коры (модель третьего поколения) // Литосфера. 2018. Т. 18. № 4. С. 500-519. https:// doi.org/10.24930/1681-9004-2018-18-4-500-519.

Jubitz K.-B., 1983. Tectonic Map of South-West Border of the East European Platform. Scale 1: 1500000 . Potsdam, Germany.

Keiding M., Kreemer C., Lindholm C.D., Gradmann S., Olesen O., Kierulf H.P., 2015. Comparison of Strain Rates and Seismicity for Fennoscandia: Depth Dependency of Deformation from Glacial Isostatic Adjustment. Geophysical Journal International 202 (2), 1021-1028. https://doi.org/ 10.1093/gji/ggv207. 
King G.C.P., Cocco M., 2001. Fault Interaction by Elastic Stress Changes: New Clues from Earthquake Sequences. Advances in Geophysics 44,1-38. https://doi.org/10.1016/ S0065-2687(00)80006-0.

Kopp M.L., 2000. The Recent Deformations of the Scythian and Southern East European Platforms as a Result of Pressure form the Arabian Plate. Geotectonics 34, 106-120.

Kopp M.L., 2004. Mobilistic Neotectonics of the Platforms of the Southeastern Europe. Proceedings GIN RAS. Iss. 552. Nauka, Moscow, 340 р. (in Russian) [Копп М.Л. Мобилистская неотектоника платформ Юго-Восточной Европы // Труды ГИН РАН. М.: Наука, 2004. Вып. 552. 340 с.].

Kostenko N.P., 1999. Geomorphology. MSU Publishing House, Moscow, 379 p. (in Russian) [Костенко Н.П. Геоморфология. М.: Изд-во МГУ, 1999. 379 с.].

Levkov E.A., Karabanov A.K., 1994. Neotectonics of Belarus. Litasfera 1, 119-126 (in Russian) [Левков Э.А., Карабанов А.К. Неотектоника Беларуси // Літасфера. 1994. № 1. C. 119-126].

Lutikov A.I., Yunga S.L., Koff G.L., Guter B., 2005. Information Bases and Premises for Refining the Initial Seismicity in the South Baltic Region. In: Applied Geoecology, Emergencies, Land Cadaster and Monitoring. Vol. 6. Moscow, p. 106-111 (in Russian) [Лутиков А.И., Юнга С.Л., Кофф Г.Л., Гутер Б. Информационные основы и предпосылки уточнения исходной сейсмичности Южной Прибалтики // Прикладная геоэкология, чрезвычайные ситуации, земельный кадастр и мониторинг. М., 2005. Вып. 6. С. 106-111].

Makarov V.I., 1996. Regional Neogeodynamics of the Platform Areas in Relation to Their Seismic Activity Assessment. Interior of Povolzhye and Pricaspian Region 13, 53-60 (in Russian) [Макаров В.И. Региональные особенности новейшей геодинамики платформенных территорий в связи с оценкой их сейсмической активности // Недра Поволжья и Прикаспия. 1996. Вып. 13. С. 53-60].

Makarova N.V., Makeev V.M., Dorozhko A.L., Sukhanova T.V., Korobova I.V., 2016. East European Craton Geodynamic Systems and Geodynamic Active Zones. Bulletin of Moscow Society of Naturalists. Geological Series 91 (4-5), 9-25 (in Russian) [Макарова Н.В., Макеев В.М., Дорожко А.Л., Суханова Т.В., Коробова И.В. Геодинамические системы и геодинамически активные зоны ВосточноЕвропейской платформы // Бюллетень МОИП. Отдел Геологический. 2016. Т. 91. Вып. 4-5. С. 9-26].

Makeev V.M., 2015. Structural-Geodynamic Conditions for Stability of Extremely Hazardous and Technically Complex Objects on Ancient Platforms. Brief PhD Thesis (Doctor of Geology and Mineralogy). Moscow, 50 p. (in Russian) [Maкеев В.М. Структурно-геодинамические условия устойчивости особо опасных и технически сложных объектов на древних платформах: Автореф. дис. ... докт. геол.мин. наук. М., 2015. 50 с.].

Mardia K., 1978. Statistics of Directional Data. Nauka, Moscow, 240 p. (in Russian) [Мардиа К. Статистический анализ угловых наблюдений. М.: Наука, 1978. 240 с.].

Nadezhka L.I., Pivovarov S.P., Efremenko M.A., Semenov A.E., 2010. About Earthquakes on the Voronezh Crystalline
Massif. Proceedings of Voronezh State University. Series: Geology 1, 233-242 (in Russian) [Надежка Л.И., Пивоваров С.П., Ефременко М.А., Семенов А.Е. 0 землетрясениях на территории Воронежского кристаллического массива // Вестник ВГУ. Серия: Геология. 2010. № 1. C. 233-242].

New Catalog of Strong Earthquakes in the USSR from Ancient Times to 1975, 1977. Nauka, Moscow, 536 p. (in Russian] [Новый каталог сильных землетрясений на территории СССР с древнейших времен до 1975 года. М.: Наука, 1977. 536 с.].

Nikonov A.A., 1977. Holocene and Contemporary Crustal Movements. Nauka, Moscow, 240 p. (in Russian) [Никонов А.А. Голоценовые и современные движения земной коры. М.: Наука, 1977. 240 с.].

Nikonov A.A., 2008. Seismicity Pattern and Thermal Anomalies in the Southern Baltic Region before and during the Kaliningrad Earthquakes of 2004. Izvestiya, Physics of the Solid Earth 44, 915-926. https://doi.org/10.1134/S10 69351308110050.

Panina L.V., 2019. Neostructural Forms and Relief of the Earth. Pero, Moscow, 115 p. (in Russian) [Панина Л.В. Новейшие структурные формы и рельеф Земли. М.: Перо, 2019. 115 с.].

Panina L.V., Zaitsev V.A., Agibalov A.O., Manuilova E.A., Bardishev G.P., 2021. Main Features of the Latest Geodynamics of the North-West and Central Caucasus. Moscow University Geology Bulletin 1, 3-14 (in Russian) [Панина Л.В., Зайцев В.А., Агибалов А.О., Мануилова Е.А., Бардышев Г.П. Основные черты новейшей геодинамики Северо-Западного и Центрального Кавказа // Вестник МГУ. Серия 4. Геология. 2021. № 1. С. 3-14].

Panina L.V., Zaitsev V.A., Manuilova E.A., Agibalov A.O., Sentsov A.A., 2017. Neotectonics of the East European Platform as a Reflection of Basement Deformations. In: Current Problems Dynamic Geology in Studying the Platform Deformations. Materials of the II Scientific Conference Dedicated to the 110th Anniversary of the Birth of N.I. Nikolaeva and A.F. Yakusheva. Pero, Moscow, p. 22-26 (in Russian) [Панина Л.В., Зайцев В.А., Мануилова Е.А., Агибалов А.О., Сенцов А.А. Новейшая тектоника Восточно-Европейской платформы как отражение деформаций фундамента // Актуальные проблемы динамической геологии при исследовании платформенных территорий: Материалы II научной конференции, посвященной 110-летию со дня рождения Н.И. Николаева и А.Ф. Якушевой. М.: Перо, 2017. С. 22-26].

Raskatov G.I., 1969. Geomorphology and Neotectonics of the Voronezh Anteclise Area. Voronezh State University Publishing House, Voronezh, 164 p. (in Russian) [Раскатов Г.И. Геоморфология и неотектоника территории Воронежской антеклизы. Воронеж: Изд-во ВГУ, 1969. 164 с.].

Rogozhin E.A., 2012. An Outline of the Regional Seismotectonics. IPE RAS Publishing House, Moscow, 340 p. (in Russian] [Рогожин Е.А. Очерки региональной сейсмотектоники. М.: Изд-во ИФЗ РАН, 2012. 340 с.].

Rogozhin E.A., Ovsyuchenko A.N., Gorbatikov A.V., Lutikov A.I., 2014a. Detailed Seismic Hazard Assessment for 
the City of Kaliningrad. Earthquake Engineering. Constructions Safety 4, 19-27 (in Russian) [Рогожин Е.А., Овсюченко А.Н., Горбатиков А.В., Лутиков А.В. Оценка сейсмической опасности г. Калининграда в детальном масштабе // Сейсмостойкое строительство. Безопасность сооружений. 2014. № 4. С. 19-27].

Rogozhin E.A., Ovsyuchenko A.N., Gorbatikov A.V., Lutikov A.I., Novikov S.S., Marahanov A.V., Stepanova M.Yu., Andreeva N.V., Lar'kov A.S., 2014b. Detailed Seismic Hazard Assessment of the Kaliningrad Territory and the Tectonic Position of the Earthquakes Occurred in 2004. Engineering Survey 12, 26-38 (in Russian) [Рогожин Е.А., Овсюченко А.Н., Горбатиков А.В., Лутиков А.И., Новиков С.С., Мараханов А.В., Степанова М.Ю., Андреева Н.В., Ларьков А.С. Детальная оценка сейсмической опасности территории Калининграда и тектонический анализ землетрясений 2004 г. // Инженерные изыскания. 2014. № 12. С. 26-38].

Rogozhin E.A., Ovsyuchenko A.N., Novikov S.S., Marahanov A.V., 2010. Seismotectonic Position of the September 21, 2004 Kaliningrad Earthquakes with $\mathrm{Mw}=4.6$ and 4.8, $\mathrm{I}_{0}=6$ и 6-7 (Western Russia). Earthquakes of North Eurasia in 2004. Geophysical Survey of RAS, Obninsk, p. 364-369 (in Russian) [Рогожин Е.А., Овсюченко А.Н., Новиков С.С., Мараханов А.В. Сейсмотектоническая позиция очагов калининградских землетрясений 21 сентября 2004 года с $M w=4.6$ и 4.8, I =6 и 6-7 (запад России) // Землетрясения Северной Евразии в 2004 году. Обнинск: ФИЦ ЕГС PAH, 2010. C. 364-369].

Rudenko M.V., Ryazheva T.I., 2004. New Bathymetric Chart of the Baltic Sea. Oceanology 44 (3), 445-448.

Seismic Catalogues and Bulletin FRS GS RAS, 2020. Available from: http://www.ceme.gsras.ru/cgi-bin/new/catalog. pl (Last Accessed September 5, 2020).

Sentsov A.A., 2019. Recent Geodynamics and Fennoscandian Shield Area Source Zones Identified by Computer Modeling. In: Tectonic Problems of Continents and Oceans. Proceedings of the LI Tectonic Conference (January 29 February 2, 2019). Vol. 2. GEOS, Moscow, p. 288-233 (in Russian] [Сенцов A.А. Современная геодинамика и зоны возможных очагов землетрясений территории Фенноскандинавского щита, установленные с помощью компьютерного моделирования // Проблемы тектоники континентов и океанов: Материалы LI тектонического совещания (29 января - 2 февраля 2019 г.). М.: ГЕОС, 2019. T. 2. C. 228-233].

Sentsov A.A., Agibalov A.O., 2021. Determination of Seismic Generation Zones of Fennoscandia According to Data of Analysis of Seismicity and Computer Geodynamic Modelling. Moscow University Geology Bulletin 1, 15-22 (in Russian) [Сенцов А.А., Агибалов А.О. Выделение зон возможных очагов землетрясений в Фенноскандии по данным анализа сейсмичности и компьютерного геодинамического моделирования // Вестник Мгу. Серия 4. Геология. 2021. № 1. С. 15-22].

Sharov N.V., Malovchinko A.A., Shukin Yu.K. (Eds), 2007. Earthquakes and Microseismicity in Relation to Problems of Recent Geodynamics of the East European Platform. Book I. Karelian Research Centre of RAS, Petrozavodsk, 381 p. (in
Russian) [Землетрясения и микросейсмичность в задачах современной геодинамики Восточно-Европейской платформы / Ред. Н.В. Шаров, А.А. Маловчинко, Ю.К. Щукин. Петрозаводск: КарНЦ РАН, 2007. Кн. 1. 381 с.].

Shik S.M., Borisov B.A., Zarrina E.P., 2004. A Project of the Regional Stratigraphic Scheme of the Pleistocene of the European Russia. Bulletin of the Commission for Study of the Quaternary 65, 102-114 (in Russian) [Шик C.M., Борисов Б.А., Заррина Е.П. Проект региональной стратиграфической схемы неоплейстоцена Европейской России // Бюллетень Комиссии по изучению четвертичного периода. 2004. № 65. С. 102-114].

Sim L., Bryatseva G., Karabanov A., Aizberg R.Y., 1995. The Neotectonic Stress of Belarus and the Baltic Countries. Technika Poszukiwań Geologicznych. Geotermia, Zrównoważony Rozwój 34 (3), 53-57.

Sokolov S.A., 2013. Structural-Geomorphological Framework and Neotectonic Zoning of the Voronezh Crystalline Massif Area. Brief PhD Thesis (Candidate of Geology and Mineralogy). Moscow, 24 p. (in Russian) [Соколов С.А. Структурно-геоморфологическое строение и неотектоническое районирование территории Воронежского кристаллического массива: Автореф. дис. ... канд. геол.-мин. наук. М., 2013. 24 с.].

State Geological Map of the Russian Federation, 2015. Central European Series. Scale 1:1000 000. Sheet N-37 (Moscow). Explanatory Note. VSEGEI Publishing House, Saint Petersburg, 462 p. (in Russian) [Государственная геологическая карта Российской Федерации. Серия Центрально-Европейская. Масштаб 1:1000000. Лист N-37 (Москва): Объяснительная записка. СПб.: Изд-во ВСЕГЕИ, 2015. 462 c.].

Storcheus A.V., 2008. Notes on the Procedure for Calculating Earthquake and Explosion Seismic Energies. In: Proceedings of the Conference Dedicated to Volcanologists Day (March 27-29, 2008). Institute of Volcanology and Seismology FEB RAS, Petropavlovsk-Kamchatsky, p. 274-281 (in Russian) [Сторчеус A.В. Заметки к методике расчета сейсмической энергий землетрясений и взрывов // Материалы конференции, посвященной Дню вулканолога (27-29 марта 2008 г.). Петропавловск-Камчатский: ИВиС ДВО РАН, 2008. С. 274-281].

Storcheus A.V., 2011. Calculating the Seismic Energy of Earthquakes and Explosions. Journal of Volcanology and Seismology 5 (5), 341-350. https://doi.org/10.1134/S074 2046311050071.

Tregub A.I., 2001. Neotectonic Structure and Stress Fields of the Voronezh Crystalline Massif Territory. Proceedings of Voronezh State University. Series: Geology 11, 33-46 (in Russian) [Трегуб А. И. Неотектоническая структура и поля напряжений территории Воронежского кристаллического массива // Вестник ВГУ. Серия: Геология. 2001. Вып. 11. С. 33-46].

Tregub A.I., 2005. Neotectonics of the Voronezh Crystalline Massif Area. PhD Thesis (Doctor of Geology and Mineralogy). Voronezh, 329 p. (in Russian) [Трегуб А.И. Неотектоника территории Воронежского кристаллического массива: Дис. ... докт. геол.-мин. наук. Воронеж, 2005. 329 с.]. 
Tregub A.I., Tregub S.A., Shevtsov D.E., 2015. Neotectonics of the Shumilinsko-Novokhopersk Zone of Faults (Voronezh Crystalline Massif). Proceedings of Voronezh State University. Series: Geology 4, 171-173 (in Russian) [Трегуб А.И., Трегуб С.А., Шевцов Д.Е. Неотектоника Шумилинско-Новохоперской зоны разломов (Воронежский кристаллический массив) // Вестник ВГУ. Серия: Геология. 2015. № 4. С. 171-173].

USGS Earthquake Hazards Program, 2019. Available from: https://earthquake.usgs.gov/ (Last Accessed December 1, 2019).

Uski M., Pelkomen E., 2004. Earthquakes in Northern Europe. Report R. Institute Seismology, University Helsinki, Sweden, $206 \mathrm{p}$.

Yudakhin F.N., Shchukin Yu.K., Makarov V.I., 2003. Deep Structure and Recent Geodynamic Processes in the Lithosphere of the East European Platform. Publishing House of the Ural Branch of RAS, Ekaterinburg, 299 p. (in Russian) [Юдахин Ф.Н., Щукин Ю.К., Макаров В.И. Глубинное строение и современные геодинамические процессы в литосфере Восточно-Европейской платформы. Екатеринбург: Изд-во УрО РАН, 2003. 299 с.].

Zaitsev V.A., Panina L.V., Manuilova E.A., Sentsov A.A., 2016. Modern Methods and Results of Neotectonic Research in the Central Part of the East European Platform. In: Current Problems of Dynamic Geology in Studies of the Platform Areas. Proceedings of the All-Russian Scientific Conference (May 24-26, 2016). Pero, Moscow, p. 49-54 (in Russian) [Зайцев В.А., Панина Л.В., Мануилова Е.А., Сенцов А.А. Современные методы и результаты изучения неотектоники центральной части Восточно-Европейской платформы // Актуальные проблемы динамической геологии при исследовании платформенных областей: Труды Всероссийской научной конференции (24-26 мая 2016 г.). М.: Перо, 2016. С. 49-54].

Zaitsev V.A., Panina L.V., Sentsov A.A., 2017. StructuralGeomorphological Studies of the Central Part of the Russian Platform. In: Tectonics of the Present-Day and Ancient Oceans and Ocean Margins. Proceedings of the XLIX Tectonic Conference Dedicated to the $100^{\text {th }}$ Anniversary of
Academician Yu.M. Pushcharovsky (January 31 - February 4, 2017). Vol. 2. GEOS, Moscow, p. 177-180 (in Russian) [Зайцев В.А., Панина Л.В., Сенцов А.А. Структурно-геоморфологические исследования центральной части Русской плиты // Тектоника современных и древних океанов и их окраин: Материалы XLIX тектонического совещания, посвященного 100-летию академика Ю.М. Пущаровского (31 января - 4 февраля 2017 г.). М.: ГЕОС, 2017. T. 2. C. $177-180]$.

Zakashansky M.S., 1963. On Oil Prospecting in the Kaliningrad Region. Oil and Gas Geology 2, 42-44 (in Russian) [3aкашанский M.С. 0 нефтепоисковых работах в Калининградской области // Геология нефти и газа. 1963. № 2. C. 42-44].

Zakharov V.S., Smirnov V.B., 2016. Physics of the Earth. INFRA-M. Moscow, 328 p. (in Russian) [Захаров B.C., Смирнов В.Б. Физика Земли. М.: ИНФРА-М, 2016. 328 с.].

Zlatopolsky A.A., 2011. New LESSA Technology Resources and Digital Terrain Map Analysis. Methodology. Current Problems in Remote Sensing of the Earth from Space 8 (3), 38-46 (in Russian) [Златопольский А.А. Новые возможности технологии LESSA и анализ цифровой модели рельефа. Методический аспект // Современные проблемы дистанционного зондирования Земли из космоса. 2011. T. 8. № 3. C. 38-46].

Zykov D.S., 2004. Structural-Kinematic Model of Neotectonic Deformations in the South of the East European Platform. Bulletin of Moscow Society of Naturalists. Geological Series 79 (4), 11-17 (in Russian) [Зыков Д.С. Структурнокинематическая модель неотектонических деформаций юга Восточно-Европейской платформы // Бюллетень МОИП. Отдел Геологический. 2004. Т. 79. Вып. 4. C. 11-17].

Zykov D.S., Poleshchuk A.V., 2016. Interaction of Geodynamic Systems of East European Platform in Recent Times. Bulletin of Moscow Society of Naturalists. Geological Series 91 (1), 3-14 (in Russian) [Зыков Д.С., Полещук А.В. Взаимодействие геодинамических систем на Восточно-Европейской платформе // Бюллетень МОИП. Отдел Геологический. 2016. Т. 91. Вып. 1. С. 3-14]. 